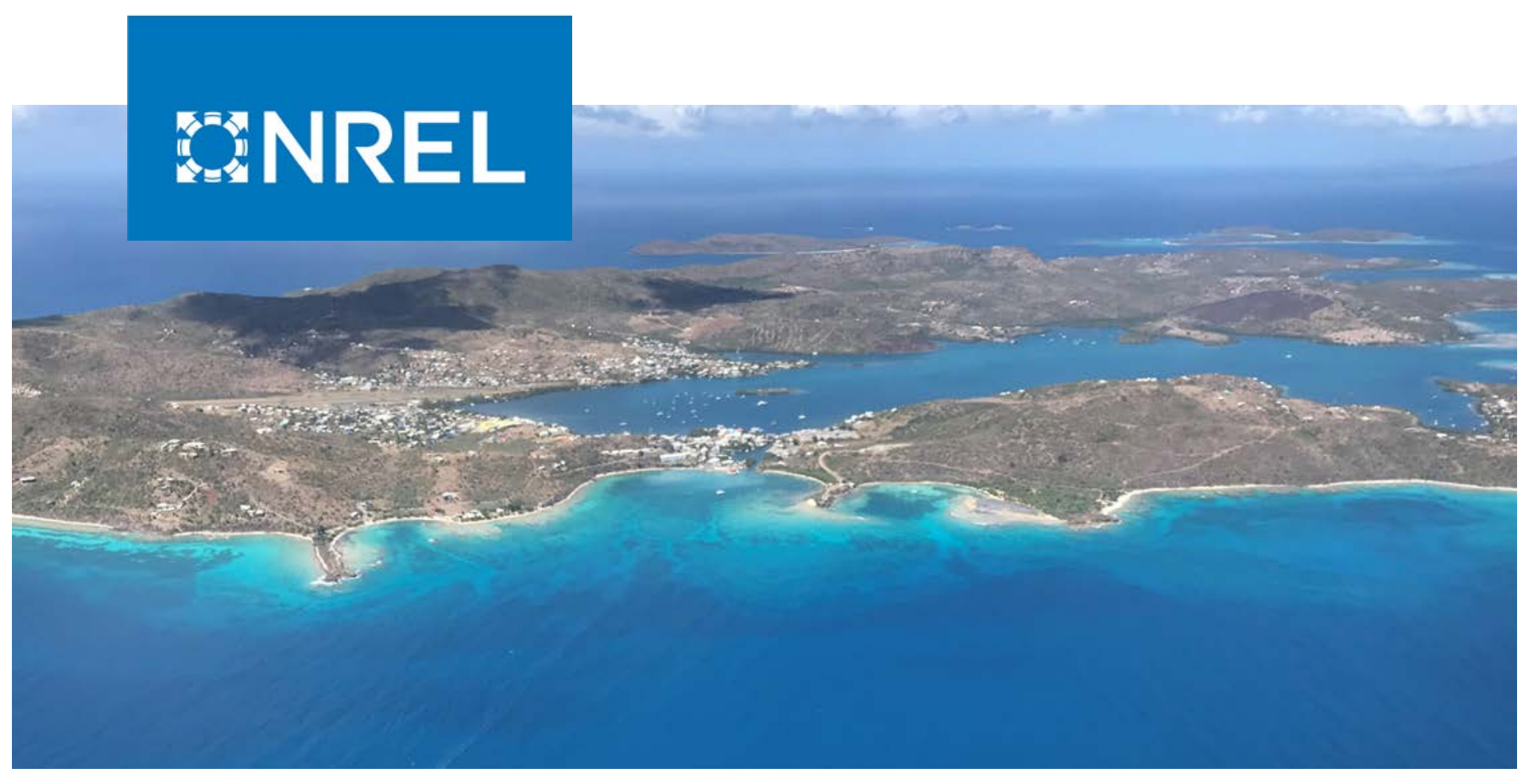

\title{
Energy Resilience Assessment for Culebra, Puerto Rico
}

\author{
James Salasovich and Gail Mosey
}

National Renewable Energy Laboratory

Produced under direction of the U.S. Environmental Protection Agency for the Municipality of Culebra, Puerto Rico, by the National Renewable

Energy Laboratory (NREL) under Interagency Agreement 16-2016.

NREL is a national laboratory of the U.S. Department of Energy

Office of Energy Efficiency \& Renewable Energy

Operated by the Alliance for Sustainable Energy, LLC

This report is available at no cost from the National Renewable Energy Laboratory (NREL) at www.nrel.gov/publications.

Strategic Partnership Project Report NREL/TP-7A40-73885

June 2019 


\section{GHREL}

\section{Energy Resilience Assessment for Culebra, Puerto Rico}

James Salasovich and Gail Mosey

National Renewable Energy Laboratory

\section{Suggested Citation}

Salasovich, James and Gail Mosey. 2019. Energy Resilience Assessment for Culebra, Puerto Rico. Golden, CO: National Renewable Energy Laboratory.

NREL/TP-7A40-73885. https://www.nrel.gov/docs/fy19osti/73885.pdf.

NREL is a national laboratory of the U.S. Department of Energy Office of Energy Efficiency \& Renewable Energy Operated by the Alliance for Sustainable Energy, LLC

This report is available at no cost from the National Renewable Energy Laboratory (NREL) at www.nrel.gov/publications.

Contract No. DE-AC36-08GO28308
Strategic Partnership Project Report NREL/TP-7A40-73885 June 2019

National Renewable Energy Laboratory 15013 Denver West Parkway Golden, CO 80401 303-275-3000 • www.nrel.gov 


\section{NOTICE}

This work was authored by the National Renewable Energy Laboratory, operated by Alliance for Sustainable Energy, LLC, for the U.S. Department of Energy (DOE) under Contract No. DE-AC36-08GO28308. Funding provided by the U.S. Environmental Protection Agency under Interagency Agreement 16-2016. The views expressed herein do not necessarily represent the views of the DOE or the U.S. Government.

The tables and figures in this report are limited to use in this report only and are not to be further disseminated or used without the permission of the sources cited.

This report is available at no cost from the National Renewable Energy Laboratory (NREL) at www.nrel.gov/publications.

U.S. Department of Energy (DOE) reports produced after 1991 and a growing number of pre-1991 documents are available free via www.OSTI.gov.

Cover photo by James Salasovich, NREL 53587.

NREL prints on paper that contains recycled content. 


\section{Contacts}

\section{City of Culebra, Puerto Rico}

William Ivan Solis Bermudez

Mayor of Culebra

Phone: 787-742-3521

\section{National Renewable Energy Laboratory}

Jimmy Salasovich

Engineer IV

Golden, Colorado

Phone: 303-384-7383

Email: james.salasovich@,nrel.gov

Gail Mosey

Project Leader

Golden, Colorado

Phone: 303-384-7356

Email: gail.mosey@nrel.gov 


\section{Acknowledgments}

The National Renewable Energy Laboratory (NREL) team thanks the Municipality of Culebra for the opportunity to perform the energy resilience assessment on Culebra, Puerto Rico. In particular, the assessment team is grateful to Mayor William Ivan Solis Bermudez and the City of Culebra staff for their generous assistance and cooperation.

\section{Contributors}

The NREL team thanks the members of the U.S. Environmental Protection Agency (EPA) and members from the University of Puerto Rico in Mayaguez for their contributions during the site assessment and for providing information included in the analysis. Contributors include:

- Fernando A. Rosado, EPA Superfund Program, Region 2 in New York City

- Terry Wesley, EPA Brownfields Program, Region 2 in New York City

- Schenine Mitchell, EPA Brownfields Program, Region 2 in New York City

- Vince Pitruzzello, EPA/Senior Service America Inc., Region 2 in New York City

- Zolymar Luna, EPA Superfund Program, Region 2 in Puerto Rico

- Jillian Panagakos, EPA Intern, The City College of the City University of New York

- Linyuan Cui, EPA Intern, The City College of the City University of New York

- Professor Eduardo Ortiz, University of Puerto Rico in Mayaguez

- Melvin Lugo Alvarez, Graduate Student, University of Puerto Rico in Mayaguez

- Francisco Matos Ortiz, Graduate Student, University of Puerto Rico in Mayaguez

- Guillermo J. Lopez Cardalda, Graduate Student, University of Puerto Rico in Mayaguez. 


\section{List of Acronyms}

ATEEC

DOE

EDA

EPA

EWDJT

FEMA

$\mathrm{ft}^{2}$

HMTRI

HVAC

IRR

ITC

kVA

$\mathrm{kW}$

$\mathrm{kWdc}$

$\mathrm{kWh}$

LED

MACRS

MGD

MW

MWdc

NREL

O\&M

PPA

PRDOH

PREPA

PRIDCO

PV

RFP

SAM

TBA

USDA

Wdc

WWTP
Advanced Technology Environmental and Energy Center

U.S. Department of Energy

U.S. Economic Development Administration

U.S. Environmental Protection Agency

Environmental Workforce Development and Job Training

Federal Emergency Management Agency

square foot

Hazardous Materials Training Research Institute

heating, ventilating, and air conditioning

internal rate of return

Investment Tax Credit

kilovolt-ampere

kilowatt

kilowatt direct current

kilowatt-hour

light-emitting diode

Modified Accelerated Cost Recovery System

million gallons per day

megawatt

megawatt direct current

National Renewable Energy Laboratory

operations and maintenance

power purchase agreement

Puerto Rico Department of Housing

Puerto Rico Electric Power Authority

Puerto Rico Industrial Development Company

photovoltaic

request for proposal

System Advisor Model

Targeted Brownfield Assessment

U.S. Department of Agriculture

watt direct current

Wastewater Treatment Plant 


\section{Executive Summary}

Culebra, Puerto Rico, is in the Caribbean Sea between the main island of Puerto Rico and the Virgin Islands. The island of Culebra is approximately 17 miles east of the main island of Puerto Rico and 12 miles west of St. Thomas in the U.S. Virgin Islands.

Since the impact of Hurricane Maria on September 20, 2017, the main underwater electric line that powered Culebra has not been in service and electricity was out for approximately 3 months. The time to repair the underwater electric line was estimated to be 5 years as of May 2018; in the meantime, two 2-MW diesel generators provide a total of $4 \mathrm{MW}$ of electricity to the island. The status of the electrical grid throughout the Puerto Rican islands has been evolving continuously after Hurricane Maria. Renewable energy hybrid microgrids (a diesel generator plus solar photovoltaics [PV] and battery storage) can provide more resilient power and increase survivability to minimize the devastating effects of future storms.

The Culebra Island and the Municipal Government of Culebra are interested in improving the energy resilience of the island's critical infrastructure. The U.S. Department of Energy's (DOE's) National Renewable Energy Laboratory (NREL) has developed core capabilities in energy resilience, and the U.S. Environmental Protection Agency (EPA) funded NREL to perform a high-level energy resilience assessment for some of the municipally owned/operated critical infrastructure on Culebra, identify potential locations where renewable energy hybrid microgrids could promote the energy resilience of critical infrastructure, and determine potential ground areas for solar PV.

In April 2018 NREL conducted high-level energy resilience site assessments at five critical infrastructure sites on Culebra: the Health Center, Police Station, Fire Station, Municipal Building, and Wastewater Treatment Plant (WWTP). Electricity usage data for these sites was not available, so the NREL team estimated the loads using building energy modeling. Next, the team performed an analysis to determine how much solar PV would be needed to make each of the sites net-zero electric on an annual basis, and to determine the effect battery storage would have on project economics. Finally, NREL identified and analyzed potential ground areas for PV throughout Culebra.

The results of NREL's analysis indicate that renewable energy hybrid microgrids appear to be economically viable on Culebra, but further analysis and detailed information-gathering are needed to optimize the mix of diesel, PV, and battery storage. 


\section{Table of Contents}

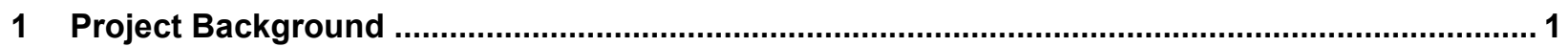

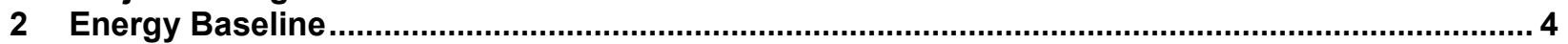

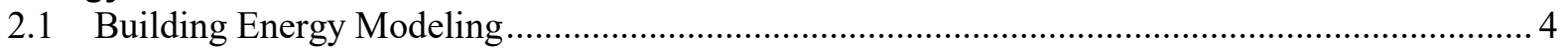

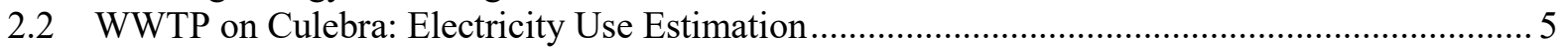

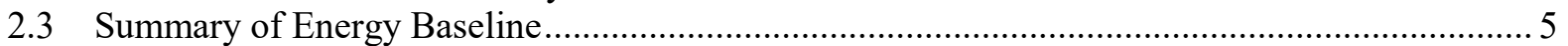

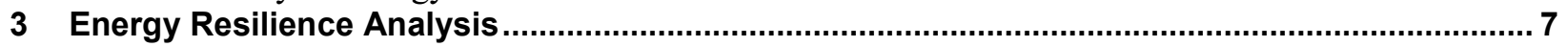

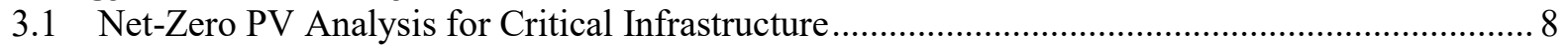

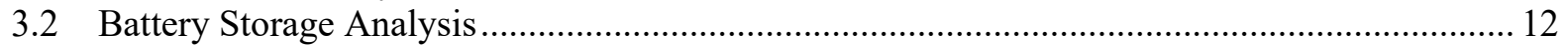

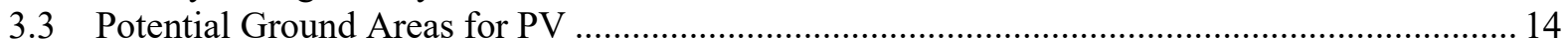

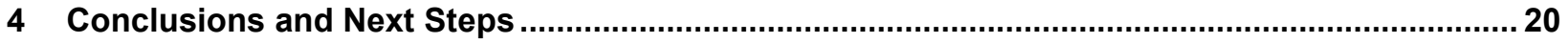

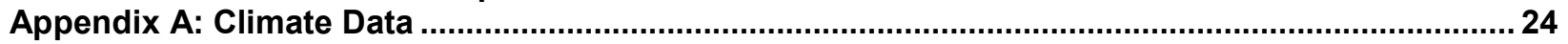

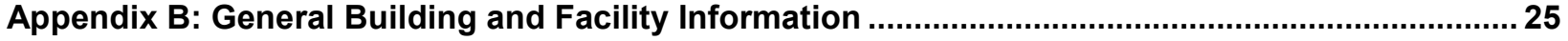

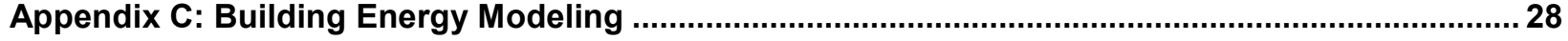

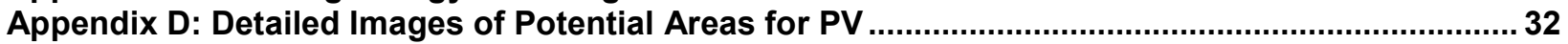

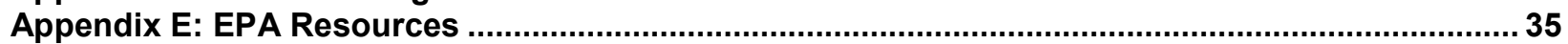




\section{List of Figures}

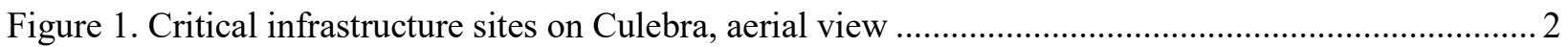

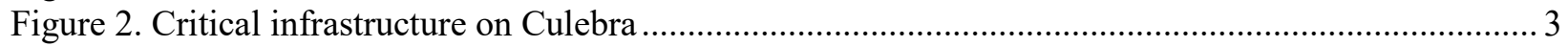

Figure 3. eQUEST model representation of the Health Center on Culebra ............................................ 4

Figure 4. eQUEST-calibrated baseline energy use estimates for the Health Center on Culebra .................. 5

Figure 5. Potential areas for PV and critical infrastructure sites on Culebra, aerial view ........................ 15

Figure C-1. Police station on Culebra eQUEST model representation.................................................28

Figure C-2. Fire station on Culebra eQUEST model representation ................................................. 28

Figure C-3. Health center on Culebra eQUEST model representation ................................................29

Figure C-4. Municipal building on Culebra eQUEST model representation........................................... 29

Figure C-5. eQUEST-calibrated baseline energy use estimates for the police station on Culebra............. 30

Figure C-6. eQUEST-calibrated baseline energy use estimates for the fire station on Culebra ................. 30

Figure C-7. eQUEST-calibrated baseline energy use estimates for the health center on Culebra............. 31

Figure C-8. eQUEST-calibrated baseline energy use estimates for the municipal building on Culebra .... 31

Figure D-1. Potential area for PV at Culebra Landfill, aerial view ...................................................... 32

Figure D-2. Potential area for PV at Municipal Lot \#1, aerial view ................................................... 33

Figure D-3. Potential area for PV at Municipal Lot \#2 and PRIDCO Roof, aerial view.......................... 33

Figure D-4. Potential area for PV at Lot \#3, aerial view .................................................................. 34

\section{List of Tables}

Table 1. Electricity Use and Peak Electrical Load Estimates for Critical Infrastructure............................ 6

Table 2. Key Factors Related to Energy Resilience in Critical Infrastructure ........................................... 7

Table 3. Major PV Analysis Inputs into the SAM Models to Analyze Net-Zero Energy in

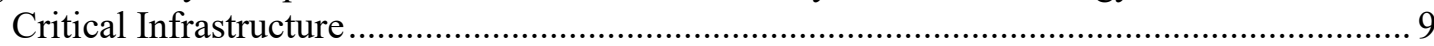

Table 4. Value of the Investment Tax Credit for Solar PV by Year ........................................................ 10

Table 5. PPA SAM Modeling Inputs and Results for Net-Zero Modeling for Critical Infrastructure ....... 11

Table 6. Direct Purchase SAM Modeling Inputs and Results for Net-Zero Modeling for

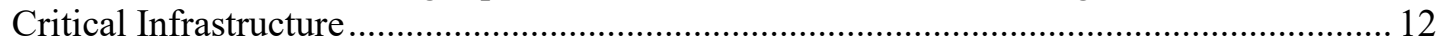

Table 7. One-Hour Battery Storage SAM Modeling Inputs and Results............................................... 14

Table 8. Major PV Analysis Inputs into the SAM Model for Potential Areas for PV ............................. 16

Table 9. PPA SAM Modeling Inputs and Results for Potential Areas for PV ......................................... 17

Table 10. Direct Purchase SAM Modeling Inputs and Results for Potential Areas for PV ...................... 18

Table 11. Distances between Potential Areas for PV and Critical Infrastructure in Feet ........................ 19

Table A-1. Culebra, Puerto Rico, Historic Weather Summary ................................................................. 24 


\section{Project Background}

The U.S. Environmental Protection Agency (EPA) and the U.S. Department of Energy's (DOE's) National Renewable Energy Laboratory (NREL) have a long history of partnering on renewable energy projects on compromised or contaminated lands. The EPA's RE-Powering America's Land ${ }^{1}$ Initiative started in 2008, and NREL collaborated with EPA to provide technical assistance for renewable energy projects on compromised or contaminated lands.

Culebra, Puerto Rico, is in the Caribbean Sea between the main island of Puerto Rico and the U.S. Virgin Islands. The island of Culebra is approximately 17 miles east of the main island of Puerto Rico and 12 miles west of St. Thomas in the Virgin Islands. At the time of the latest U.S. census in 2010 , the 7,400-acre island had a population of 1,818 people. ${ }^{2}$ Tourism is the main industry on Culebra. Appendix A provides details about the island's climate.

Since the impact of Hurricane Maria on September 20, 2017, the main underwater electric line that powered Culebra has not been in service and electricity was out for approximately 3 months. The time to repair the underwater electric line was estimated to be 5 years as of May 2018; in the meantime, two 2-MW diesel generators provide a total of $4 \mathrm{MW}$ of electricity to the island. The status of the electrical grid throughout the Puerto Rican islands has been evolving continuously after Hurricane Maria. Renewable energy hybrid microgrids (a diesel generator plus solar photovoltaics [PV] plus battery storage) can provide more resilient power and increase survivability to minimize the devastating effects of future storms. A key aspect to any microgrid is having controls that allow the system to operate independent of the grid.

The Culebra Island and the Municipal Government of Culebra are interested in improving the energy resilience of the island's critical infrastructure. NREL has developed core capabilities in energy resilience, and EPA funded NREL to perform a high-level energy resilience assessment for some of the municipally owned/operated critical infrastructure.

The major goal of the site assessments was to identify potential locations where renewable energy hybrid microgrids could promote the energy resilience of critical infrastructure and determine potential ground areas for solar PV. During the week of April 30, 2018, NREL staff visited Culebra to conduct energy resilience site assessments, collect data, discuss challenges and goals, and identify potential opportunities for installing microgrids to increase the resilience of critical infrastructure. Following the visit, the NREL team performed energy modeling and analyses to quantify potential savings to assist the municipal government with implementation prioritization. It is important to note that many of the sites listed below had backup diesel generators on site at the time of the assessment.

\footnotetext{
1 "RE-Powering America's Land," U.S. Environmental Protection Agency, accessed October 2018, https://www.epa.gov/re-powering.

2 "QuickFacts, Culebra Municipio, Puerto Rico," U.S. Census Bureau, accessed October 2018, https://www.census.gov/quickfacts/culebramunicipiopuertorico.
} 
For this study, the NREL team identified five critical infrastructure sites based on whether the buildings or sites would need to continue operating during electrical outages in order to provide basic necessities for the community. The critical infrastructure sites that were identified include:

1. Health Center

2. Police Station

3. Fire Station

4. Municipal Building

5. Wastewater Treatment Plant (WWTP)

Figure 1 provides an aerial view of the critical infrastructure sites on Culebra, and Figure 2 is a compilation of photos of the critical infrastructure sites. Appendix B presents details of the critical buildings and the WWTP.

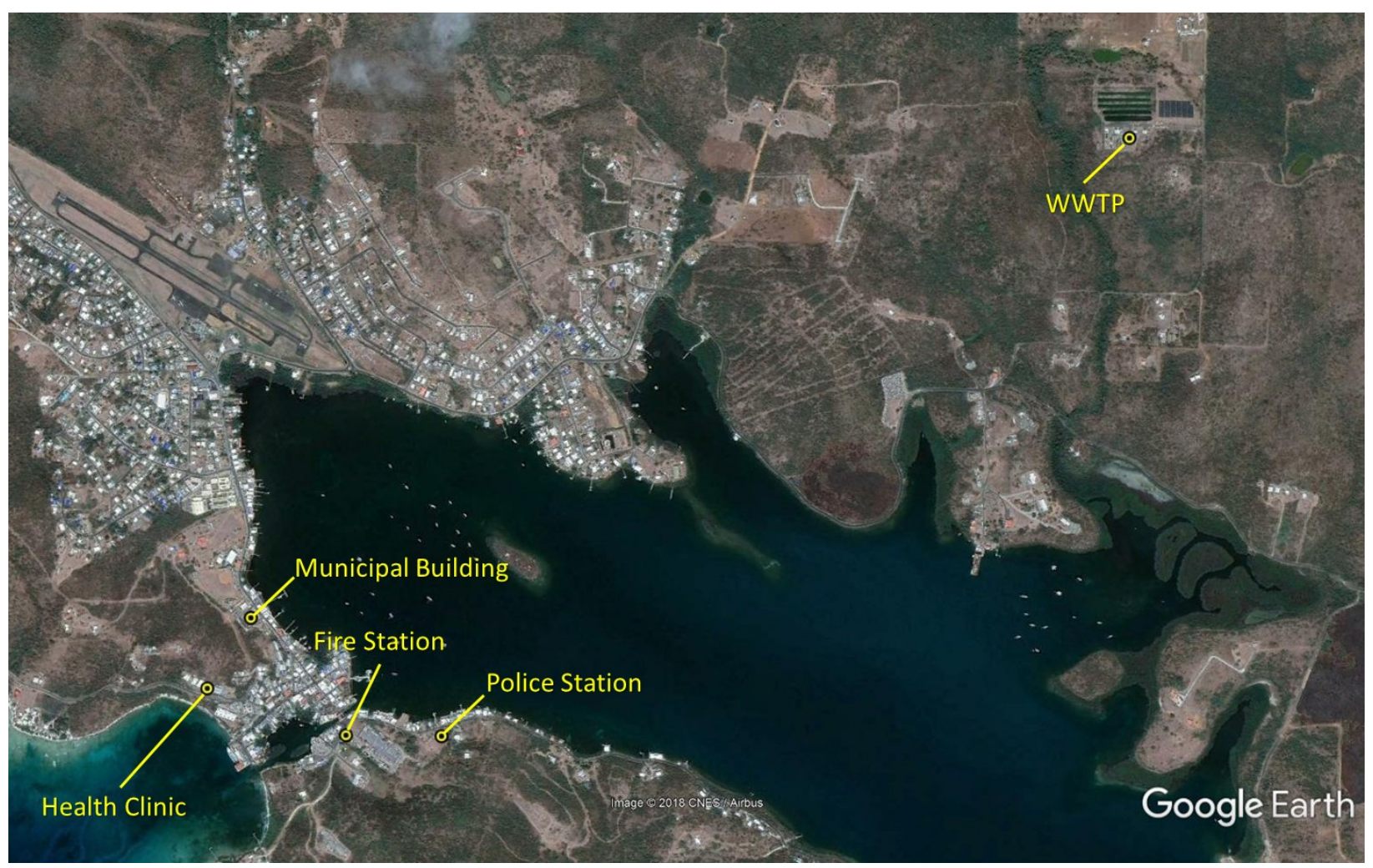

Figure 1. Critical infrastructure sites on Culebra, aerial view

(c) 2018 Google Earth, alterations by James Salasovich, NREL 


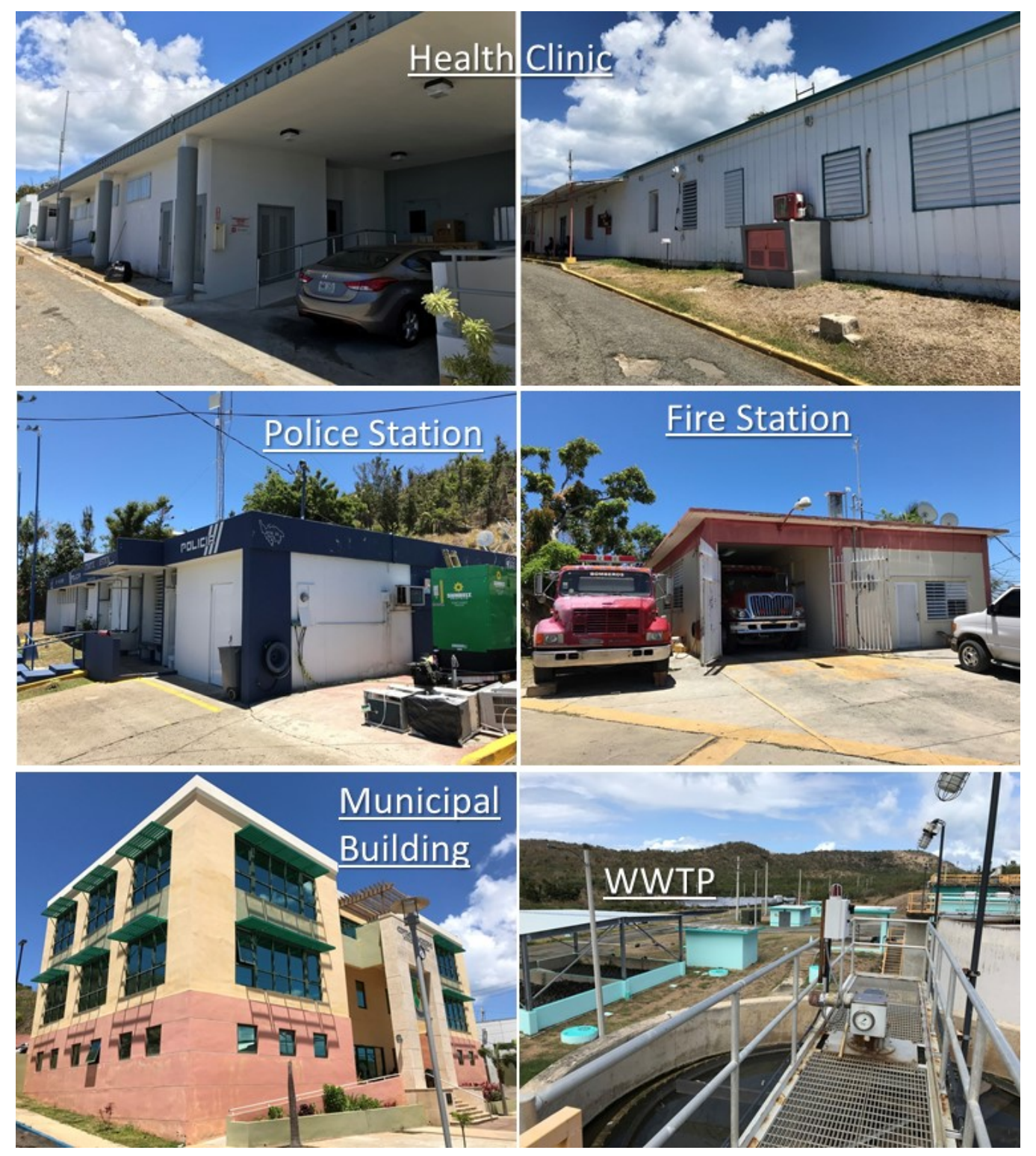

Figure 2. Critical infrastructure on Culebra

Photos by Jimmy Salasovich, NREL

To analyze the critical infrastructure sites on Culebra, it is necessary to first understand the energy use of the critical buildings and WWTP. Electric utility data was not available for any of the critical buildings or the WWTP. Hourly or 15-minute electric utility data would be ideal for doing a detailed energy resilience analysis and will be required for any follow-on work to perform more detailed analyses for energy resilience on Culebra.

For this high-level study, NREL used the best available data to estimate the hourly electric loads of the buildings and the Culebra WWTP. The Puerto Rico Electric Power Authority (PREPA) is the local electric utility provider, and the NREL team assumed a flat rate of $\$ 0.21 / \mathrm{kWh}$ (costs are in USD) for all the analyses presented in this paper, which is based on the current electric rate on Culebra that was derived from electrical data provided by the site. Section 2 outlines the methodology NREL used to develop an energy baseline for Culebra's critical infrastructure sites. 


\section{Energy Baseline}

An energy baseline is essential to understanding current energy consumption and identifying the highest consumers (e.g., HVAC, lights, fans, pumping). Electric utility data, including hourly or 15-minute electricity use data, is typically used to establish an energy baseline and would ideally feed into an energy resilience analysis. However, because this information was not available for any of Culebra's critical infrastructure sites, the NREL team used information collected during the Culebra site assessments to estimate energy use for the Health Center, Police Station, Fire Station, and Municipal Building, and they used average electricity use data for wastewater treatment plants in the United States to estimate the hourly electricity use of the Culebra WWTP.

The following sections outline the baseline energy models NREL developed, along with assumptions and justification for that analysis. Note that NREL's building energy modeling process was consistent for each of the buildings. The detailed building energy modeling characteristics for the Police Station, Fire Station, and Municipal Building are presented in Appendix C.

\subsection{Building Energy Modeling}

The NREL team created an eQUEST ${ }^{3}$ building energy model of the critical facilities on Culebra to provide a baseline of current energy use that could feed into the energy resilience analysis. The team modeled the existing operating conditions of HVAC, lighting, and plug load systems after performing a walk-through energy audit of the facilities. An example graphical representation of the building energy model developed in eQUEST for the Health Center is shown in Figure 3. The representations of the other building energy models are presented in Appendix C. The geometry of the buildings was simplified for modeling purposes while still allowing accurate simulations of energy transfer through all surfaces in the buildings.

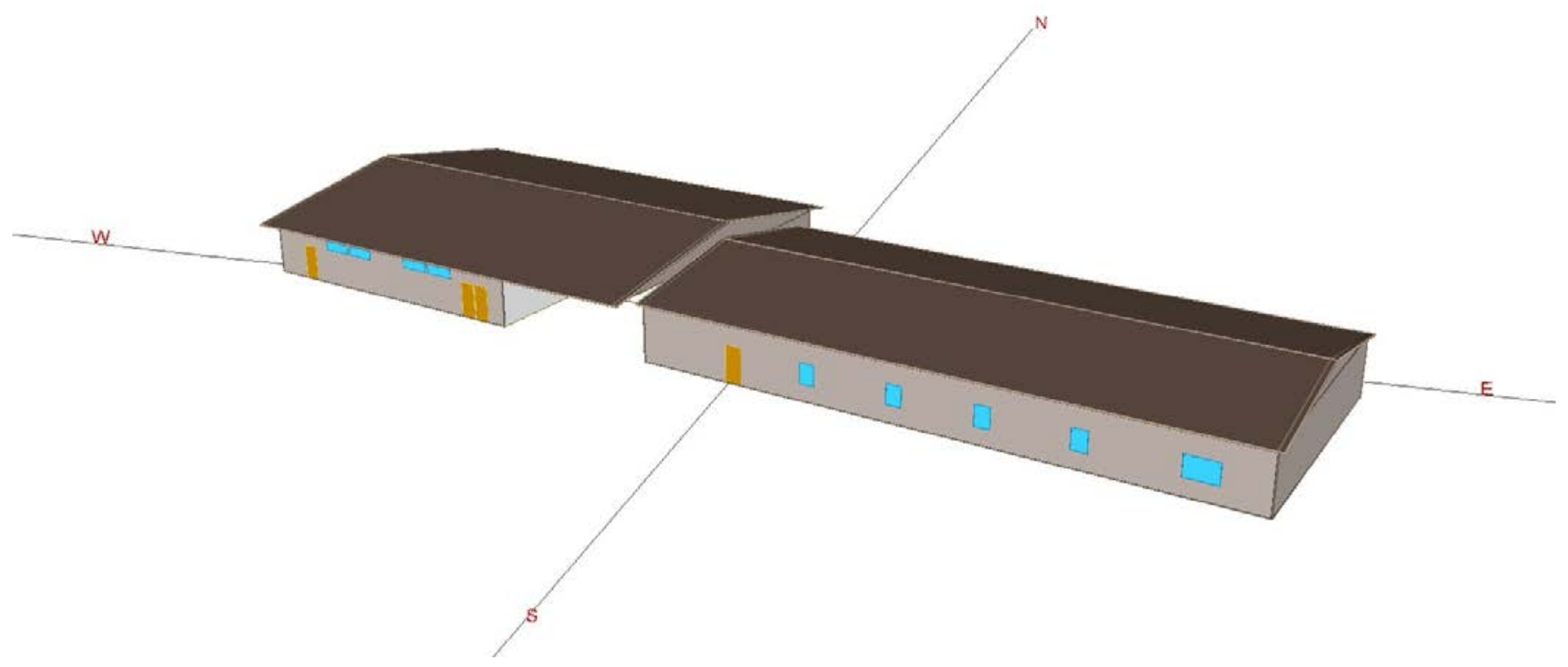

Figure 3. eQUEST model representation of the Health Center on Culebra Image generated using eQUEST

3 “eQUEST Quick Energy Simulation Tool,” DOE2.com, accessed October 2018, http://www.doe2.com/equest/. 
The NREL team used the eQUEST building energy model to generate current hourly energy use estimates for critical facilities on Culebra. As an example, the Health Center electricity end uses are shown in Figure 4. As shown, space cooling (blue) is the largest electricity consumer, followed by miscellaneous equipment (green; accounts for all plug loads, including things like computers, TVs, refrigerators, etc.) and lighting (yellow).

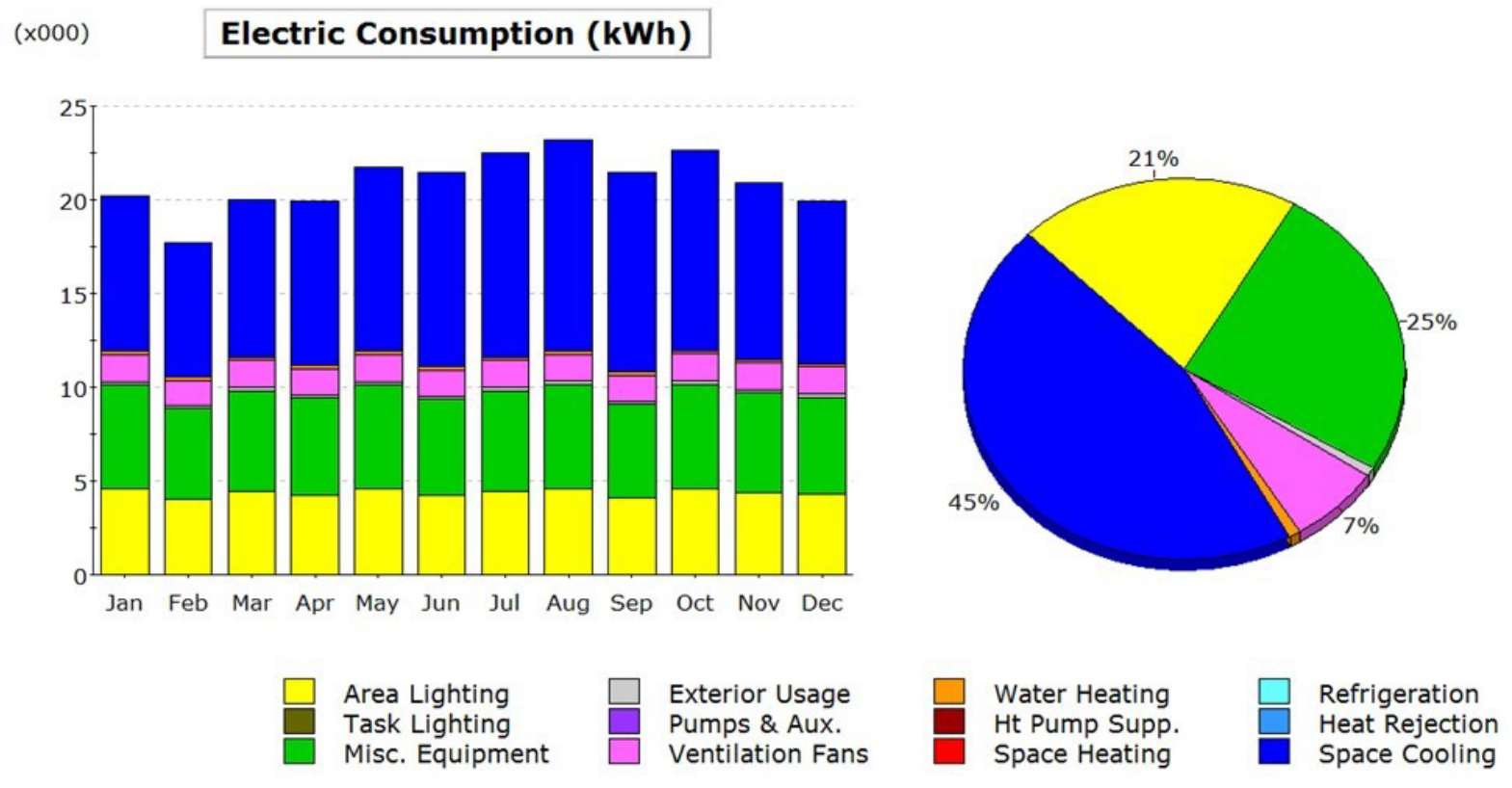

Figure 4. eQUEST-calibrated baseline energy use estimates for the Health Center on Culebra

Graphs generated using eQUEST

\subsection{WWTP on Culebra: Electricity Use Estimation}

NREL staff estimated the hourly electricity use of the WWTP on Culebra to provide a baseline of current energy use. Culebra's WWTP has an operating capacity of treating 0.2 million gallons per day (MGD) of wastewater. Electricity data was not available for the WWTP at the time of the site visit. The average wastewater treatment plant uses 3,400 kWh/MGD to treat the waste, ${ }^{4}$ which served as the basis for NREL's annual electricity use estimate of 248,200 kWh/year for the WWTP on Culebra. The NREL team assumed the Culebra WWTP's electricity use to be a constant flat load, which does not capture the peak load when motors and equipment are being turned on, but was determined to be a reasonable first estimate after discussions with site operators.

\subsection{Summary of Energy Baseline}

Because actual electricity use data for Culebra's critical sites was not available, the estimated hourly electricity use and annual peak electric load for each site were taken from the energy

\footnotetext{
4 “Quantifying Energy Use in the U.S. Public Water Industry-A Summary,” EWRI Currents Volume 16 Number 4 Fall 2014, accessed October 2018, http://www.hansenallenluce.com/wp-content/uploads/2015/11/Energy-UseWater-Sector.pdf.
} 
baseline analysis using eQUEST building energy modeling described in this section and are summarized in Table 1.

Table 1. Electricity Use and Peak Electrical Load Estimates for Critical Infrastructure

\begin{tabular}{|c|c|c|c|c|c|}
\hline & $\begin{array}{l}\text { Health } \\
\text { Clinic }\end{array}$ & $\begin{array}{l}\text { Police } \\
\text { Station }\end{array}$ & Fire Station & $\begin{array}{l}\text { Municipal } \\
\text { Building }\end{array}$ & WWTP \\
\hline Building Area ${ }^{a}\left(\mathrm{ft}^{2}\right)$ & 11,000 & 1,700 & 1,500 & 20,000 & $\mathrm{~N} / \mathrm{A}$ \\
\hline $\begin{array}{l}\text { Annual Electricity Use } \\
\text { (kWh) }\end{array}$ & 251,712 & 41,086 & 27,316 & 203,085 & 248,200 \\
\hline $\begin{array}{l}\text { Energy Use Intensity } \\
\left(\mathrm{kWh} / \mathrm{ft}^{2}\right)\end{array}$ & 23 & 24 & 18 & 10 & $\mathrm{~N} / \mathrm{A}$ \\
\hline $\begin{array}{l}\text { Current Electricity Rate } \\
(\phi / k W h)\end{array}$ & 21.0 & 21.0 & 21.0 & 21.0 & 21.0 \\
\hline Annual Electricity Cost (\$) & $\$ 52,859$ & $\$ 8,628$ & $\$ 5,736$ & $\$ 42,648$ & $\$ 52,122$ \\
\hline Peak Electric Load (kW) & 43.5 & 7.9 & 5.2 & 79.6 & $28.3^{c}$ \\
\hline
\end{tabular}

N/A—Not applicable.

a Estimated using Google Earth.

${ }^{b}$ Estimated using building energy modeling and published data for the WWTP since electric bills were not available.

c $28.3 \mathrm{~kW}$ is assumed as a flat load since electric bills were not available for the WWTP.

As shown, the Health Clinic, WWTP, and the Municipal Building have the highest electrical loads of the five sites. The Municipal Building has the highest peak electric load at $79.6 \mathrm{~kW}$ because of its relatively high air-conditioning loads. Due to their relatively small physical size, both the Police Station and the Fire Station have significantly lower annual electricity uses and peak loads compared to the Health Clinic, WWTP, and Municipal Building. 


\section{Energy Resilience Analysis}

It should be noted that NREL would need to gather more information to do a more detailed energy resilience analysis. In particular, the team would need more detailed data on the actual hourly electricity use of each of the critical buildings and sites, along with information such as the electrical design (e.g., electrical drawings, one-line diagrams) and critical components of each building or site, fuel availability, sizes of existing generators and/or existing renewable energy systems, existing generator run times, and any planned energy efficiency projects.

There are many key factors that play into the energy resilience of a site, and Table 2 lists those NREL assessed for this study. All of the sites were deemed highly critical, with the exception of the Municipal Building, which was considered to have a medium level of criticality and was included because it was planned to serve as a logistics hub in the event of a prolonged electrical grid outage. All of the highly critical buildings and the WWTP had backup diesel generators onsite. Only the WWTP had a battery bank, which was installed after Hurricane Maria and which on-site staff identified as temporary. During this site visit, the NREL team focused primarily on ground-mounted photovoltaic (PV) systems.

Table 2. Key Factors Related to Energy Resilience in Critical Infrastructure

\begin{tabular}{|l|c|c|c|c|c|}
\hline & $\begin{array}{c}\text { Health } \\
\text { Clinic }\end{array}$ & $\begin{array}{c}\text { Police } \\
\text { Station }\end{array}$ & Fire Station & $\begin{array}{c}\text { Municipal } \\
\text { Building }\end{array}$ & WWTP \\
\hline $\begin{array}{l}\text { Criticality of the } \\
\text { Building or Site }\end{array}$ & High & High & High & Medium & High \\
\hline $\begin{array}{l}\text { Annual Electricity Use } \\
\text { (kWh) }\end{array}$ & 251,712 & 41,086 & 27,316 & 203,085 & 248,200 \\
\hline $\begin{array}{l}\text { Annual Peak Electric } \\
\text { Load (kW) }\end{array}$ & 43.5 & 7.9 & 5.2 & 79.6 & 28.3 \\
\hline $\begin{array}{l}\text { Current On-Site } \\
\text { Backup Diesel } \\
\text { Generator Size } \\
\text { (kW/kVA) }\end{array}$ & $35 / 41$ & $60 / 70$ & $17 / 20$ & Unknown & $320 / 375$ \\
\hline $\begin{array}{l}\text { Current On-Site Diesel } \\
\text { Storage (Gallons) }\end{array}$ & Unknown & Unknown & Unknown & Unknown & Unknown \\
\hline $\begin{array}{l}\text { Current On-Site } \\
\text { Battery Storage }\end{array}$ & None & None & None & None & $\begin{array}{c}\text { Tesla battery } \\
\text { bank; size } \\
\text { unknown }\end{array}$ \\
\hline $\begin{array}{l}\text { Potential Areas for On- } \\
\text { Site PV }\end{array}$ & \multicolumn{7}{|r|}{ Ground areas were the focus of this study } & \\
\hline
\end{tabular}

Based on the amount of data obtained during the site visits, the assessment team determined that the energy resilience analysis would focus on how much PV is required to make the five sites net-zero electric on an annual basis and how the addition of battery storage affects the economics. This study does not analyze the value of resilience from adding PV and batteries nor does it analyze how adding PV and batteries affects how much additional time a critical building or site could operate during electrical outage or the probabilities associated with those times. The 
energy resilience aspect is analyzed assuming PV is installed along with smart inverters that allow buildings and/or sites to operate, to some extent, during electrical outages.

A net-zero electric building or site produces all of the electricity it uses on an annual basis. It is important to note that there are times when the distributed generation system (in this case solar PV) will produce more or less than the building or site needs at any given time, but the system is sized so that it generates all of the electricity consumed on an annual basis. Given that the current electricity rate is a flat $\$ 0.21 / \mathrm{kWh}$, the main benefit of adding battery storage would be to increase resilience, since the batteries would not be able to be used to reduce electricity costs through peak shaving - i.e., switching to an alternate electricity source like batteries during peak times, such as hottest times of the year when the electrical loads are typically the highest, to avoid paying high peak kilowatt charges from the electric utility.

\subsection{Net-Zero PV Analysis for Critical Infrastructure}

The NREL team used the System Advisor $\operatorname{Model}^{5}$ (SAM) to determine the PV system sizes required to make each of the critical infrastructure sites net-zero electric on an annual basis. All of the buildings analyzed in this study are all-electric buildings, and most of the energy use at the WWTP is electric. For certain critical infrastructure types, only a portion of a site might be deemed critical. But for all of the buildings and the WWTP in this study, NREL assumed 100\% of the load at each of the sites is critical and therefore $100 \%$ of the electric load is provided on an annual basis. A more detailed study would be needed to determine whether there are different levels of criticality (i.e., what building end uses or operations are the most critical) within the various sites and to determine whether certain portions of a site could be deenergized to make the most critical functions more resilient.

The major inputs used in the SAM PV system modeling are presented in Table 3 . The PV system size is based on generating $100 \%$ of the annual electricity. The $\$ 2.15 /$ watt installed cost assumption is based on discussions with local PV developers in Puerto Rico. This cost does not include any site preparation (e.g., clearing trees, leveling land), but the city indicated it has the equipment to do the site preparation for a relatively low cost.

5 “System Advisor Model,” National Renewable Energy Laboratory, accessed October 2018, https://sam.nrel.gov/. 
Table 3. Major PV Analysis Inputs into the SAM Models to Analyze Net-Zero Energy in Critical Infrastructure

\begin{tabular}{|l|c|c|c|c|c|}
\hline & $\begin{array}{c}\text { Health } \\
\text { Clinic }\end{array}$ & $\begin{array}{c}\text { Police } \\
\text { Station }\end{array}$ & $\begin{array}{c}\text { Fire } \\
\text { Station }\end{array}$ & $\begin{array}{c}\text { Municipal } \\
\text { Building }\end{array}$ & WWTP \\
\hline PV System Size (kWdc) & 165 & 27 & 18 & 133 & 163 \\
\hline Tilt (degrees) & 20 & 20 & 20 & 20 & 20 \\
\hline Azimuth & South & South & South & South & South \\
\hline Analysis Period (years) & 25 & 25 & 25 & 25 & 25 \\
\hline $\begin{array}{l}\text { Installed Cost of PVa } \\
\text { (\$/watt) }\end{array}$ & 2.15 & 2.15 & 2.15 & 2.15 & 2.15 \\
\hline $\begin{array}{l}\text { Current Electricity Rate } \\
\text { (ф/kWh) }\end{array}$ & 21.0 & 21.0 & 21.0 & 21.0 & 21.0 \\
\hline Sell-Back Rate ( $\mathbf{\phi} / \mathbf{k W h )}$ & 21.0 & 21.0 & 21.0 & 21.0 & 21.0 \\
\hline
\end{tabular}

a The installed cost accounts for new tariffs on solar.

b The sell-back rate needs to be confirmed with the local utility provider, PREPA.

The NREL team considered two different financing models in the SAM modeling: a power purchase agreement (PPA) and a direct purchase by the municipality. There are tradeoffs when considering these two financing options.

For the PPA financing scenario, a third-party private solar developer installs, owns, and operates the PV system and the municipality enters into a long-term (typically 20 to 25 years) contract where the municipality agrees to purchase the electricity generated from the PV system at a given rate for the length of the contract with an annual cost escalation. One of the main advantages of PPAs is that private developers can take advantage of the $30 \%$ Federal Renewable Energy Investment Tax Credit (ITC) and the Modified Accelerated Cost Recovery System (MACRS) tax depreciation system with the current $100 \%$ Bonus Depreciation (see the DSIRE ${ }^{6}$ website for a complete list of incentives in Puerto Rico). The thinking is that the developer can take advantage of these incentives and pass on some of the savings to the site. The main drawback of this financing option is that the developer needs to be profitable and typically requires an internal rate of return (IRR) of $8 \%$.

For the direct purchase financing scenario, the municipality would purchase the PV system with a combination of capital and/or financing, and then the annual energy cost savings would go directly to the site. One disadvantage of this financing option is that municipalities are non-taxpaying entities and would not be able to take advantage of any of the tax-based incentives, which currently are considerable. Another disadvantage is that the municipality would have to come up

6 “DSIRE Programs," N.C. Clean Energy Technology Center, accessed October 2018, http://programs.dsireusa.org/system/program?state=TER. 
with the capital to install the PV system. The main advantage is that the municipality would be able to capture all of the energy savings associated with the PV system without having to pass a portion of those saving on to a PPA developer. If the municipality were to purchase the system, the operations and maintenance (O\&M) would need to be performed in-house or contracted out. O\&M for PV systems is typically in the range of $\$ 15$ to $\$ 18 / \mathrm{kW}$ per year, which is relatively low. Jobs would be created to support the O\&M of PV systems, but the number of jobs created would be relatively modest. The number of PV installation jobs created when there is a thriving solar PV market is typically significantly higher than any O\&M jobs that are created.

\subsubsection{PPA Modeling for Net-Zero Energy in Critical Infrastructure}

NREL used SAM modeling to analyze the various critical infrastructure sites from a net-zeroelectric standpoint, and Table 5 presents the inputs and results for the PPA financing scenario. It should be noted that PV system sizes and the annual electricity generation values are consistent between the PPA models and the direct purchase models. The model assumed the developer's required IRR to be $8 \%$, and it assumed the developer could take advantage of the $30 \%$ ITC and MACRS with $100 \%$ bonus depreciation.

It is important to note the $30 \%$ ITC was extended by The Consolidated Appropriations Act in December 2015. The most significant changes to the extension involve a gradual step down of credits for solar technologies beginning in 2019 through 2022 (see Table 4). The credit is allotted in the year in which the project begins commercial operations and vests linearly over a 5-year period. If the project owner sells the project before the end of the 5-year period, the unvested portion of the credit will be recaptured by the Internal Revenue Service. More information on the ITC and eligible technologies is available at the Solar Energy Industries Association. ${ }^{7}$

Table 4. Value of the Investment Tax Credit for Solar PV by Year

\begin{tabular}{|l|c|c|c|c|c|c|}
\hline Technology & $\mathbf{1 2 / 3 1 / 1 8}$ & $\mathbf{1 2 / 3 1 / 1 9}$ & $\mathbf{1 2 / 3 1 / 2 0}$ & $\mathbf{1 2 / 3 1 / 2 1}$ & $\mathbf{1 2 / 3 1 / 2 2}$ & Future Years \\
\hline Solar PV & $30 \%$ & $30 \%$ & $26 \%$ & $22 \%$ & $10 \%$ & $10 \%$ \\
\hline
\end{tabular}

Results from the PPA SAM modeling are given in Table 5. The main result when analyzing the results from PPA financing scenarios is the first-year PPA price, which is the cost of electricity the municipality would be paying the developer for all of the electricity generated by the PV systems. In general, if the first-year PPA price is less than what the site is currently paying for electricity, this is a good indicator that the economics are favorable for both the developer and the site. For example, the site currently pays $21.0 \notin / \mathrm{kWh}$, and the PPA price for the electricity is $9.17 \mathrm{c} / \mathrm{kWh}$ for all the sites in the first year. This is a $56 \%$ savings in electricity costs in that first year. There is typically also a cost escalation rate to consider when entering a PPA, which is generally in the range of $1 \%-3 \%$. As long as the cost escalation of traditionally generated electricity is also in this range, then the project will be profitable throughout the entire project life.

\footnotetext{
7 "Solar Investment Tax Credit," Solar Energy Industries Association, accessed October 2018, https://www.seia.org/initiatives/solar-investment-tax-credit-itc.
} 
Table 5. PPA SAM Modeling Inputs and Results for Net-Zero Modeling for Critical Infrastructure

\begin{tabular}{|l|c|c|c|c|c|c|}
\hline & $\begin{array}{c}\text { Health } \\
\text { Clinic }\end{array}$ & $\begin{array}{c}\text { Police } \\
\text { Station }\end{array}$ & $\begin{array}{c}\text { Fire } \\
\text { Station }\end{array}$ & $\begin{array}{c}\text { Municipal } \\
\text { Building }\end{array}$ & WWTP & Total \\
\hline PV System Size (kWdc) & 165 & 27 & 18 & 133 & 163 & 506 \\
\hline $\begin{array}{l}\text { Annual Electricity } \\
\text { Generation (kWh) }\end{array}$ & 251,904 & 41,221 & 27,480 & 203,050 & 248,851 & 772,506 \\
\hline $\begin{array}{l}\text { Developer Internal Rate } \\
\text { of Return Target }\end{array}$ & $8 \%$ & $8 \%$ & $8 \%$ & $8 \%$ & $8 \%$ & $8 \%$ \\
\hline $\begin{array}{l}\text { Incentives Available to } \\
\text { Private Developers }\end{array}$ & \multicolumn{2}{|c|}{$30 \%$ ITC and MACRS with $100 \%$ Bonus Depreciation } \\
\hline $\begin{array}{l}\text { Developer PV System } \\
\text { Installed Cost with 30\% } \\
\text { ITC (\$) }\end{array}$ & $\$ 231,000$ & $\$ 37,800$ & $\$ 25,200$ & $\$ 186,200$ & $\$ 228,200$ & $\$ 708,400$ \\
\hline $\begin{array}{l}\text { First-Year PPA Price } \\
\text { ( } \mathbf{k} / \mathbf{k W h}\end{array}$ & 9.17 & 9.17 & 9.17 & 9.17 & 9.17 & 9.17 \\
\hline
\end{tabular}

\subsubsection{Direct Purchase Modeling for Net-Zero Energy in Critical Infrastructure}

NREL used SAM modeling to analyze the various critical infrastructure sites from a net-zeroelectric standpoint, and the inputs and results for the direct purchase financing scenario are given in Table 6. It should be noted that the PV system installed cost is higher than the PPA case because the municipality would not be able to take advantage of the $30 \%$ ITC. The annual cost savings is the $21.0 \mathrm{c} / \mathrm{kWh}$ multiplied by the annual energy generation of the PV system. As shown, the annual cost savings are considerable given the relatively high electric rate on Culebra. The net present value is the total value of the PV system for the entire 25-year analysis period in today's dollars. A positive net present value project indicates a profitable project, and the more positive the more profitable. The simple payback periods are shown in the last row, and the estimated simple payback for all the systems is 6.8 years, which indicates favorable economics given that PV systems typically last 25 years. 
Table 6. Direct Purchase SAM Modeling Inputs and Results for Net-Zero Modeling for Critical Infrastructure

\begin{tabular}{|l|c|c|c|c|c|c|}
\hline & $\begin{array}{c}\text { Health } \\
\text { Clinic }\end{array}$ & $\begin{array}{c}\text { Police } \\
\text { Station }\end{array}$ & $\begin{array}{c}\text { Fire } \\
\text { Station }\end{array}$ & $\begin{array}{c}\text { Municipal } \\
\text { Building }\end{array}$ & WWTP & Total \\
\hline $\begin{array}{l}\text { PV System Size } \\
\text { (kWdc) }\end{array}$ & 165 & 27 & 18 & 133 & 163 & 506 \\
\hline $\begin{array}{l}\text { Annual Electricity } \\
\text { Generation (kWh) }\end{array}$ & 251,904 & 41,221 & 27,480 & 203,050 & 248,851 & 772,506 \\
\hline $\begin{array}{l}\text { PV System Installed } \\
\text { Cost (\$) }\end{array}$ & $\$ 330,000$ & $\$ 54,000$ & $\$ 36,000$ & $\$ 266,000$ & $\$ 326,000$ & $\$ 1,012,000$ \\
\hline $\begin{array}{l}\text { Incentives (\$) } \\
\text { None }\end{array}$ & None & None & None & None & None \\
\hline $\begin{array}{l}\text { Savings (\$) } \\
\text { Levtricity Cost }\end{array}$ & $\$ 52,859$ & $\$ 8,629$ & $\$ 5,736$ & $\$ 42,620$ & $\$ 51,878$ & $\$ 161,722$ \\
\hline $\begin{array}{l}\text { Levelized Cost of } \\
\text { Energy ( } / \text { /kWh) }\end{array}$ & 10.18 & 10.18 & 10.18 & 10.18 & 10.18 & 10.18 \\
\hline Net Present Value (\$) & $\$ 401,379$ & $\$ 65,661$ & $\$ 43,754$ & $\$ 323,547$ & $\$ 396,077$ & $\$ 1,230,418$ \\
\hline $\begin{array}{l}\text { Simple Payback } \\
\text { (years) }\end{array}$ & 6.8 & 6.8 & 6.8 & 6.8 & 6.8 & 6.8 \\
\hline
\end{tabular}

a The simple payback accounts for PV panel degradation over the 25-year life of the system.

\subsection{Battery Storage Analysis}

The NREL team also used SAM modeling to determine how the addition of battery storage to the PV systems described in the previous section affects the overall economics. It is important to note that this analysis does not consider the entire microgrid because the diesel generator is not modeled and cannot be modeled in SAM.

For this high-level analysis, the battery bank was sized to power the entire peak load for 1 hour. The team chose 1 hour as a good starting point to analyze how including batteries in a potential microgrid system affects the economics of the project. However, this is not suggesting that adding 1 hour of battery storage to a potential microgrid of the five critical sites is the optimal sizing. More detailed data (e.g., actual hourly electrical loads, on-site diesel storage capacities, what portions of the sites' loads are critical) and more detailed analysis and modeling would be needed to determine the optimal mix of diesel generator, PV, and battery storage. This more detailed energy resilience analysis can be done using REopt, ${ }^{8}$ a tool developed by NREL to analyze the optimal mix of renewable energy, conventional energy generation, and energy storage for various types of projects, including microgrids.

\footnotetext{
8 "REopt: Renewable Energy Integration and Optimization," National Renewable Energy Laboratory, accessed October 2018, https://reopt.nrel.gov/.
} 
It is important to note that adding 1 hour of storage does not mean the critical infrastructure would only be able to withstand a 1-hour power outage. Any potential microgrids on Culebra would use a combination of diesel generator, PV, and battery, and each of these components work in conjunction to extend the overall operating time during an electrical grid outage. NREL analyses ${ }^{9}$ have been done that show adding even a half-hour of battery storage to a renewable energy hybrid microgrid could extend the probability of surviving an outage substantially depending on how much diesel storage is on site and the time of year the outage happened.

Results from the SAM PV plus battery analysis (with diesel generator not included) are presented in Table 7.

The battery costs are listed at $\$ 500 / \mathrm{kWh}$ of battery capacity and $\$ 1,000 / \mathrm{kW}$ of power capacity. The results between the PV-only and PV plus battery cases are shown in the lower rows of the table in gray. As shown, the net present value is lowered with the addition of batteries, and the simple payback is increased. The percent reduction in the net present value suggests that adding a battery to the system results in a relatively modest reduction. The important thing to keep in mind is that there is value in the increased resilience from the battery storage that is not accounted for in this analysis; therefore, this should simply be seen as a way to understand the costs of adding battery storage. As has been noted throughout this report, more information from the sites and more detailed analyses would be needed to determine the optimal mix of diesel generator, $\mathrm{PV}$, and batteries for microgrids at each of these critical infrastructure sites on Culebra.

\footnotetext{
${ }^{9}$ Jeffrey J. Cook, Eliza Hotchkiss, Xiangkun Li, and Jesse Cruce. "Planning for the Storm: Considering Renewable Energy for Critical Infrastructure Resilience,” Journal of Emergency Management, forthcoming.
} 
Table 7. One-Hour Battery Storage SAM Modeling Inputs and Results

\begin{tabular}{|l|c|c|c|c|c|}
\hline & $\begin{array}{c}\text { Health } \\
\text { Clinic }\end{array}$ & $\begin{array}{c}\text { Police } \\
\text { Station }\end{array}$ & $\begin{array}{c}\text { Fire } \\
\text { Station }\end{array}$ & $\begin{array}{c}\text { Municipal } \\
\text { Building }\end{array}$ & WWTP \\
\hline Peak Electric Load (kW) & 43.5 & 7.9 & 5.2 & 79.6 & 28.3 \\
\hline $\begin{array}{l}\text { Battery Design: Hours of } \\
\text { Increased Operation (hours) }\end{array}$ & 1 & 1 & 1 & 1 & 1 \\
\hline Battery Capacity (kWh) & 44 & 8 & 6 & 80 & 29 \\
\hline Battery Power (kW) & 44 & 8 & 6 & 80 & 29 \\
\hline Energy Capacity Cost (\$/kWh) & $\$ 500$ & $\$ 500$ & $\$ 500$ & $\$ 500$ & $\$ 500$ \\
\hline Power Capacity Cost (\$/kW) & $\$ 1,000$ & $\$ 1,000$ & $\$ 1,000$ & $\$ 1,000$ & $\$ 1,000$ \\
\hline Total PV Installed Cost (\$) & $\$ 330,000$ & $\$ 54,000$ & $\$ 36,000$ & $\$ 266,000$ & $\$ 326,000$ \\
\hline $\begin{array}{l}\text { Total Battery Bank Installed Cost } \\
\text { (\$) }\end{array}$ & $\$ 66,000$ & $\$ 12,000$ & $\$ 9,000$ & $\$ 120,000$ & $\$ 43,500$ \\
\hline $\begin{array}{l}\text { Total PV + Battery Installed Cost } \\
\text { (\$) }\end{array}$ & $\$ 396,000$ & $\$ 66,000$ & $\$ 45,000$ & $\$ 386,000$ & $\$ 369,500$ \\
\hline $\begin{array}{l}\text { PV-Only Direct Purchase Net } \\
\text { Present Value (\$) }\end{array}$ & $\$ 401,379$ & $\$ 65,661$ & $\$ 43,754$ & $\$ 323,547$ & $\$ 396,077$ \\
\hline $\begin{array}{l}\text { PV Plus Battery Direct Purchase } \\
\text { Net Present Value (\$) }\end{array}$ & $\$ 352,471$ & $\$ 57,053$ & $\$ 37,274$ & $\$ 234,665$ & $\$ 363,735$ \\
\hline \% Change in Net Present Value & $12 \%$ & $13 \%$ & $15 \%$ & $27 \%$ & $8 \%$ \\
\hline $\begin{array}{l}\text { PV-Only Direct Purchase Simple } \\
\text { Payback } \text { (years) }\end{array}$ & 6.8 & 6.8 & 6.8 & 6.8 & 6.8 \\
\hline $\begin{array}{l}\text { PV Plus Battery Direct Purchase } \\
\text { Simple Payback (years) }\end{array}$ & 8.1 & 8.2 & 8.4 & 9.7 & 7.6 \\
\hline Sized to meet the peak entectical & & & & & \\
\hline
\end{tabular}

a Sized to meet the peak electrical load.

b The simple payback accounts for PV panel degradation over the 25-year life of the system.

\subsection{Potential Ground Areas for PV}

A key focus of this study was to determine potential ground areas for PV. The strategy was to identify lands that could support ground-mounted PV systems and potentially be close enough to the critical infrastructure sites to be viable options. For this high-level analysis, the costs to tie the critical infrastructure sites to the various potential land areas are not considered. However, rough distances from the potential areas for PV and the critical infrastructure sites are provided later in this section.

To get an understanding of potential shading issues and ground-clearing/preparation issues, the site assessment team toured various municipally owned land areas throughout Culebra that could support ground-mounted PV systems. The areas considered are listed below, and a Google Earth image of the potential ground areas for PV (green) along with the locations of the critical infrastructure sites (yellow text) that were analyzed for this study are presented in Figure 5. Note that one roof area (blue) was considered for PV, which is the Puerto Rico Industrial 
Development Company (PRIDCO) roof. More detailed views of the potential areas for PV, along with a description of each site, are provided in Appendix D.

1. Culebra Landfill

2. Municipal Lot \#1 (northwest of runway)

3. Municipal Lot \#2 (near library and PRIDCO)

4. PRIDCO Roof

5. Lot \#3 (east of WWTP)

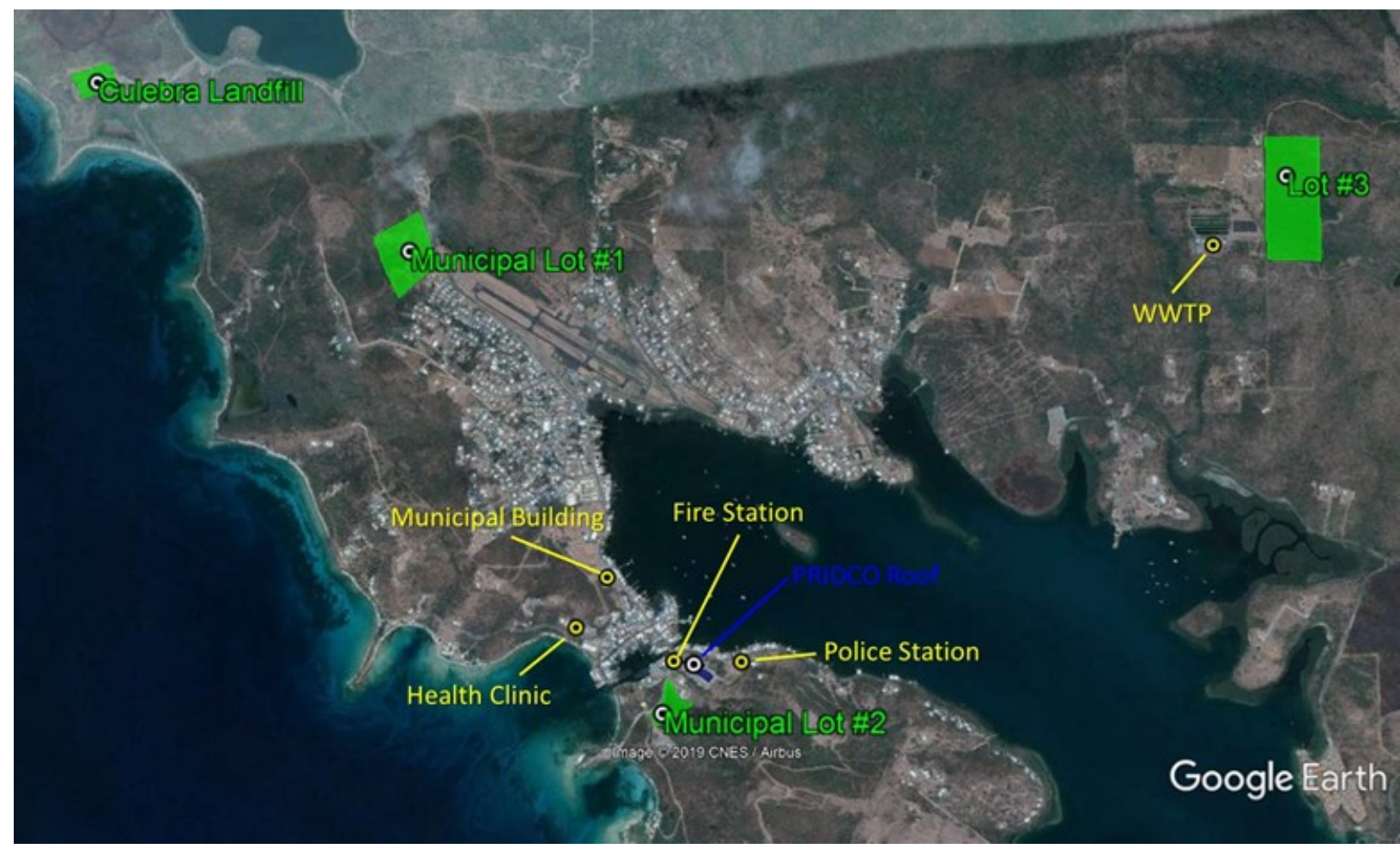

Figure 5. Potential areas for PV and critical infrastructure sites on Culebra, aerial view

(C) 2018 Google Earth, alterations by James Salasovich, NREL

The Culebra Landfill and Municipal Lot \#1 are the furthest from any critical infrastructure sites, which could add to the PV system costs depending on locations where the solar power could tie back into the electrical grid. The Municipal Lot \#1 has the advantage of being a highly visible site along the major road that links the city to the main tourist attraction, Flamenco Beach. Choosing a highly visible site like this could have a positive impact on public relations, and it could demonstrate how the municipality values renewable energy. The Municipal Lot \#2 and the PRIDCO Roof are the most centrally located areas for PV in relation to the critical infrastructure sites. The Lot \#3 is in close proximity to the WWTP. At the time of the NREL study, Lot \#3 was assessed as a municipally owned lot. However, town officials confirmed that Lot \#3 is not owned by the Municipality of Culebra. While the NREL study is not suggesting the use of Lot \#3 for solar generation, the study illustrates the potential for generating solar energy on open land.

The NREL team performed SAM modeling for both PPA and direct purchase financing options for each of the potential areas for PV. The analysis assumes that all of the available area at each 
site can be developed into solar. The major inputs used for these SAM runs are the same as the inputs used in the net-zero analysis described in a previous section, and Table 8 lists the major inputs for this round of analysis. The PV system size is based on generating $100 \%$ of annual electricity. The $\$ 2.15 /$ watt installed cost assumption is based on discussions with local PV developers in Puerto Rico. This cost does not include any site preparation (e.g., clearing trees, leveling land) as the city indicated it has the equipment to do the site preparation itself for a relatively low cost. It should also be noted that building on landfills typically adds $10 \%-15 \%$ to the cost to accommodate for ballasting and additional site design requirements (e.g., maintaining water runoff).

Table 8. Major PV Analysis Inputs into the SAM Model for Potential Areas for PV

\begin{tabular}{|l|c|c|c|c|c|}
\hline & $\begin{array}{c}\text { Culebra } \\
\text { Landfill }\end{array}$ & Muni Lot \#1 & $\begin{array}{c}\text { Muni Lot } \\
\text { \#2 }\end{array}$ & $\begin{array}{c}\text { PRIDCO } \\
\text { Roof }\end{array}$ & Lot \#3 \\
\hline Ground or Roof Area & Ground & Ground & Ground & Roof & Ground \\
\hline $\begin{array}{l}\text { Potential Area (acres or } \\
\text { ft }^{2} \text { ) }\end{array}$ & 3.6 acres & 12.0 acres & 2.8 acres & $36,000 \mathrm{ft}^{2}$ & 25.0 acres \\
\hline $\begin{array}{l}\text { Assumed Packing Density } \\
\text { for Ground-Mounted PV } \\
\text { (acres/MWdc) }\end{array}$ & 2.5 & 2.5 & 2.5 & N/A & 2.5 \\
\hline $\begin{array}{l}\text { Assumed Packing Density } \\
\text { for Roof-Mounted PV } \\
\text { (Wdc/ft } \text { ) }\end{array}$ & N/A & N/A & N/A & 10.0 & N/A \\
\hline $\begin{array}{l}\text { Potential PV System Size } \\
\text { (kWdc) }\end{array}$ & 1,440 & 4,800 & 1,120 & 360 & 10,000 \\
\hline $\begin{array}{l}\text { Tilt (degrees) } \\
\text { Azimuth }\end{array}$ & 20 & 20 & 20 & 10 & 20 \\
\hline Analysis Period (years) & 25 & 25 & 25 & 25 & 25 \\
\hline $\begin{array}{l}\text { Installed Cost of PV } \\
\text { (\$/watt) }\end{array}$ & 2.15 & 2.15 & 2.15 & 2.15 & 2.15 \\
\hline $\begin{array}{l}\text { Current Electricity Rate } \\
\text { (ф/kWh) }\end{array}$ & 21.0 & 21.0 & 21.0 & 21.0 & 21.0 \\
\hline
\end{tabular}

\subsubsection{PPA Modeling for Potential Areas for PV}

The NREL team used SAM modeling to analyze the potential areas for PV, and the inputs and results for the PPA financing scenario are presented in Table 9. It should be noted that the PV system sizes and the annual electricity generation values are consistent between the PPA models and the direct purchase models. The model assumed the developer's required IRR to be $8 \%$, and it assumed the developer could take advantage of the 30\% ITC and MACRS with $100 \%$ bonus depreciation. The main result when analyzing the results from PPA financing scenarios is the first-year PPA price, which is the cost of electricity the municipality would be paying the developer for all of the electricity generated by the PV systems. In general, if the first-year PPA price is less than what the municipality is currently paying for electricity, this is a good indicator that the economics are favorable for both the developer and the municipality. For example, the 
municipality currently pays $21.0 \phi / \mathrm{kWh}$, and the PPA price for the electricity is the range of $9.17-9.23 \phi / \mathrm{kWh}$ for all the sites in the first year. This represents a $56 \%$ savings in electricity costs in that first year. There is typically a cost escalation rate to consider when entering a PPA, which is typically in the range of $1 \%-3 \%$. As long as the cost of traditionally generated electricity escalation is also in this range, then the project will be profitable throughout the entire project life.

Table 9. PPA SAM Modeling Inputs and Results for Potential Areas for PV

\begin{tabular}{|c|c|c|c|c|c|c|}
\hline & $\begin{array}{l}\text { Culebra } \\
\text { Landfill }\end{array}$ & $\begin{array}{l}\text { Muni Lot } \\
\quad \# 1\end{array}$ & $\begin{array}{l}\text { Muni Lot } \\
\quad \# 2\end{array}$ & $\begin{array}{l}\text { PRIDCO } \\
\text { Roof }\end{array}$ & Lot \#3 & Total \\
\hline $\begin{array}{l}\text { PV System Size } \\
\text { (kWdc) }\end{array}$ & 1,440 & 4,800 & 1,120 & 360 & 10,000 & 17,720 \\
\hline $\begin{array}{l}\text { Annual Electricity } \\
\text { Generation (kWh) }\end{array}$ & $2,198,439$ & $7,328,129$ & $1,709,897$ & 545,724 & $15,266,934$ & $27,049,123$ \\
\hline $\begin{array}{l}\text { Developer Internal } \\
\text { Rate of Return } \\
\text { Target }\end{array}$ & $8 \%$ & $8 \%$ & $8 \%$ & $8 \%$ & $8 \%$ & $8 \%$ \\
\hline $\begin{array}{l}\text { Incentives } \\
\text { Available to } \\
\text { Private } \\
\text { Developers }\end{array}$ & \multicolumn{6}{|c|}{$30 \%$ ITC and MACRS with $100 \%$ Bonus Depreciation } \\
\hline $\begin{array}{l}\text { Developer PV } \\
\text { System Installed } \\
\text { Cost with } 30 \% \text { ITC } \\
\text { (\$) }\end{array}$ & $\$ 2,167,200$ & $\$ 7,224,000$ & $\$ 1,685,600$ & $\$ 541,800$ & $\$ 15,050,000$ & $\$ 26,668,600$ \\
\hline $\begin{array}{l}\text { First Year PPA } \\
\text { Price ( } \phi / k W h)\end{array}$ & 9.17 & 9.17 & 9.17 & 9.23 & 9.17 & 9.18 \\
\hline
\end{tabular}

\subsubsection{Direct Purchase Modeling for Potential Areas for PV}

NREL used SAM modeling to analyze the potential areas for PV, and the inputs and results for the direct purchase financing scenario are presented in Table 10. It should be noted that the PV system installed cost is higher than the PPA case because the municipality would not be able to take advantage of the $30 \%$ ITC. The annual cost savings is the $21.0 \% / \mathrm{kWh}$ multiplied by the annual energy generation of the PV system. As shown, the annual cost savings are considerable given the relatively high electric rate on Culebra. The net present value is the total value of the PV system for the entire 25-year analysis period in today's dollars. A positive net present value project indicates a profitable project, and the more positive, the more profitable. The simple payback periods are shown in the last row, and the estimated simple payback for all the systems is 6.8 years, which indicates favorable economics given that PV systems typically last 25 years. 
Table 10. Direct Purchase SAM Modeling Inputs and Results for Potential Areas for PV

\begin{tabular}{|l|c|c|c|c|c|c|}
\hline & $\begin{array}{c}\text { Culebra } \\
\text { Landfill }\end{array}$ & Muni Lot \#1 & $\begin{array}{c}\text { Muni Lot } \\
\# \mathbf{2}\end{array}$ & $\begin{array}{c}\text { PRIDCO } \\
\text { Roof }\end{array}$ & Lot \#3 & Total \\
\hline $\begin{array}{l}\text { PV System Size } \\
\text { (kW) }\end{array}$ & 1,440 & 4,800 & 1,120 & 360 & 10,000 & 17,720 \\
\hline $\begin{array}{l}\text { Annual } \\
\text { Electricity } \\
\text { Generation } \\
\text { (kWh) }\end{array}$ & $2,198,439$ & $7,328,129$ & $1,709,897$ & 545,724 & $15,266,934$ & $27,049,123$ \\
\hline $\begin{array}{l}\text { PV System } \\
\text { Installed Cost (\$) }\end{array}$ & $\$ 3,096,000$ & $\$ 10,320,000$ & $\$ 2,408,000$ & $\$ 774,000$ & $\$ 21,500,000$ & $\$ 38,098,000$ \\
\hline $\begin{array}{l}\text { Incentives (\$) } \\
\text { Annual } \\
\text { Electricity Cost } \\
\text { Savings (\$) }\end{array}$ & $\$ 461,670$ & $\$ 1,538,904$ & $\$ 359,074$ & $\$ 114,598$ & $\$ 3,206,052$ & $\$ 5,680,298$ \\
\hline $\begin{array}{l}\text { Levelized Cost of } \\
\text { Energy ( } \mathbf{k} / \mathbf{k W h}\end{array}$ & 10.18 & 10.18 & 10.18 & 10.25 & 10.18 & 10.19 \\
\hline $\begin{array}{l}\text { Net Present } \\
\text { Value (\$) }\end{array}$ & $\$ 3,503,203$ & $\$ 11,677,512$ & $\$ 2,724,687$ & $\$ 865,537$ & $\$ 24,328,238$ & $\$ 43,099,177$ \\
\hline $\begin{array}{l}\text { Simple Payback } \\
\text { (years) }\end{array}$ & 6.8 & 6.8 & 6.8 & 6.8 & 6.8 & 6.8 \\
\hline
\end{tabular}

a The simple payback accounts for PV panel degradation over the 25-year life of the system.

As both the PPA and direct purchase results show, all of the potential land areas available for PV could support at least one, and in some cases all, of the electrical use on an annual basis of the five critical infrastructure sites assessed in this study. Some of the potential land areas for PV are near the critical infrastructure (e.g., Lot \#3 is right across the street from the WWTP), and other potential land areas for PV are relatively far away from any of the critical infrastructure sites (e.g., Culebra Landfill). The approximate distances "as the crow flies" are provided in Table 11. As shown, the distances between the potential areas for PV and the critical infrastructure vary greatly, and further analysis would need to be completed to determine the optimal areas for pairing PV with the critical infrastructure. 
Table 11. Distances between Potential Areas for PV and Critical Infrastructure in Feet

\begin{tabular}{|l|c|c|c|c|c|}
\hline $\begin{array}{l}\text { Distance between } \\
\text { Potential PV Sites and } \\
\text { Critical Infrastructure (ft) }\end{array}$ & $\begin{array}{l}\text { Culebra } \\
\text { Landfill }\end{array}$ & Muni Lot \#1 & Muni Lot \#2 & $\begin{array}{c}\text { PRIDCO } \\
\text { Roof }\end{array}$ & Lot \#3 \\
\hline Health Center & 9,300 & 5,100 & 1,500 & 1,500 & 10,500 \\
\hline Police Station & 11,200 & 6,600 & 1,000 & 500 & 9,200 \\
\hline Fire Station & 10,500 & 6,100 & 500 & 200 & 9,800 \\
\hline Municipal Building & 9,200 & 4,700 & 1,800 & 1,500 & 9,800 \\
\hline WWTP & 14,600 & 10,200 & 8,900 & 8,400 & 1,000 \\
\hline
\end{tabular}

\subsubsection{Community Solar PV}

The results from both the PPA and direct purchase scenarios described above can provide a highlevel sense of the PV energy generation from these potential areas if community solar projects were to be implemented. The electricity from larger-scale solar projects not only has the potential to power critical infrastructure, but it also has the potential to power local homes and/or businesses. Because long-term electricity data for the island was not available, further analysis of the impacts of larger community solar projects (e.g., percent solar power provided to the entire island) was not possible. Another option could be to sell the electricity to neighboring islands (e.g., Vieques), if there is excess, using the existing transmission infrastructure that connects Culebra to Vieques. It is important to note that $17.7 \mathrm{MW}$ of potential PV was identified, which is considerably more than the $4 \mathrm{MW}$ of diesel-generated electricity currently used to power the entire island. However, because solar power is intermittent (e.g., the sun does not always shine), further analysis would be needed to determine financially viable potential sizing of community solar projects. 


\section{Conclusions and Next Steps}

At the end of April 2018, NREL conducted high-level energy resilience site assessments at five critical infrastructure sites on Culebra: the Health Center, Police Station, Fire Station, Municipal Building, and WWTP. This study does not go into the value of resilience from adding PV and batteries nor does it go into an analysis of how adding PV and batteries affects how much additional time a critical building or site could operate during an electrical outage or the probabilities associated with those times. The energy resilience aspect is analyzed assuming PV is installed along with smart inverters that allow buildings and/or sites to operate, to some extent, during electrical outages.

Electricity usage data for Culebra's critical infrastructure sites was not available, so the NREL team estimated the loads using building energy modeling. Next, the team did an analysis to determine how much solar PV would be needed to make each of the sites net-zero electric on an annual basis, and to determine the effect battery storage would have on project economics. Finally, the analysis provided detailed information on the potential ground locations for PV throughout Culebra - the site staff wanted to focus on installing ground-mounted PV systems because of the damage incurred to the roof-mounted systems during Hurricane Maria.

A summary of the net-zero-energy SAM analysis for the critical infrastructure is presented in Table 12 for both the PPA case and the direct purchase case. For the PPA case, the first year PPA price is considerably lower than the current electric rate of $21.0 \notin / \mathrm{kWh}$, which indicates it is financially viable. For the direct purchase case, all of the net present values are positive, and the simple payback periods are relatively low at 6.8 years.

The results between the PV-only and PV plus battery cases are shown in the lower rows of Table 12. As shown, the net present value is lowered with the addition of batteries, and the simple payback is increased. It should be noted that the value of the increased resilience from battery storage is not accounted for in this analysis; therefore, this should simply be seen as a way to understand the costs of adding battery storage. As has been noted throughout this paper, more information from the sites and more detailed analyses would be needed to determine the optimal mix of diesel generator, PV, and batteries for microgrids at each of these critical infrastructure sites on Culebra. 
Table 12. Summary of SAM Modeling Inputs and Results for Net-Zero Modeling for Critical Infrastructure

\begin{tabular}{|c|c|c|c|c|c|c|}
\hline & $\begin{array}{l}\text { Health } \\
\text { Clinic }\end{array}$ & $\begin{array}{l}\text { Police } \\
\text { Station }\end{array}$ & $\begin{array}{l}\text { Fire } \\
\text { Station }\end{array}$ & $\begin{array}{l}\text { Municipal } \\
\text { Building }\end{array}$ & WWTP & Total \\
\hline PV System Size (kW) & 165 & 27 & 18 & 133 & 163 & 506 \\
\hline $\begin{array}{l}\text { Annual Electricity } \\
\text { Generation (kWh) }\end{array}$ & 251,904 & 41,221 & 27,480 & 203,050 & 248,851 & 772,506 \\
\hline \multicolumn{7}{|l|}{ PV-Only PPA Results } \\
\hline $\begin{array}{l}\text { PPA Analysis First-Year } \\
\text { PPA Price }(\phi / k W h)\end{array}$ & 9.17 & 9.17 & 9.17 & 9.17 & 9.17 & 9.17 \\
\hline \multicolumn{7}{|c|}{ PV-Only Direct Purchase Results } \\
\hline $\begin{array}{l}\text { Levelized Cost of Energy } \\
(\phi / \mathrm{kWh})\end{array}$ & 10.18 & 10.18 & 10.18 & 10.18 & 10.18 & 10.18 \\
\hline $\begin{array}{l}\text { Direct Purchase Analysis } \\
\text { Net Present Value (\$) }\end{array}$ & $\$ 401,379$ & $\$ 65,661$ & $\$ 43,754$ & $\$ 323,547$ & $\$ 396,077$ & $\$ 1,230,418$ \\
\hline $\begin{array}{l}\text { Direct Purchase Analysis } \\
\text { Simple Payback }{ }^{\text {a }} \text { (years) }\end{array}$ & 6.8 & 6.8 & 6.8 & 6.8 & 6.8 & 6.8 \\
\hline \multicolumn{7}{|c|}{ PV Plus Battery Direct Purchase Results } \\
\hline $\begin{array}{l}\text { Direct Purchase PV Plus } \\
\text { Battery Analysis Net } \\
\text { Present Value (\$) }\end{array}$ & $\$ 352,471$ & $\$ 57,053$ & $\$ 37,274$ & $\$ 234,665$ & $\$ 363,735$ & $\$ 1,045,198$ \\
\hline $\begin{array}{l}\text { Direct Purchase PV Plus } \\
\text { Battery Analysis Simple } \\
\text { Payback (years) }^{\text {a (yim }}\end{array}$ & 8.1 & 8.2 & 8.4 & 9.7 & 7.6 & 8.4 \\
\hline
\end{tabular}

a The simple payback accounts for PV panel degradation over the 25-year life of the system.

To get an understanding of potential shading issues and ground-clearing/preparation issues, the site assessment team toured various municipally owned land areas throughout Culebra that could support ground-mounted PV systems. A summary of the SAM analysis for the potential ground areas for PV is provided in Table 13. Both the PPA and direct purchase results show that all of the potential land areas available for PV could support at least some, and in some cases, all of the electrical use on an annual basis of the five critical infrastructure sites presented in this study.

Some of the potential land areas for PV are near the critical infrastructure (e.g., Lot \#3 is right across the street from the WWTP), and others are relatively far away from any of the critical infrastructure sites (e.g., Culebra Landfill)—see Table 11. The distances between the potential areas for PV and the critical infrastructure vary greatly, and further analysis would need to be completed to determine the optimal areas for pairing PV with the critical infrastructure. There are other metrics (e.g., what buildings or sites are the most critical, how much site preparation is needed, etc.) that would also need to be considered when prioritizing projects that weren't analyzed for this study.

The results in Table 13 can also be used to get a high-level sense of the PV energy generation from these potential areas if community solar projects were to be implemented. The electricity 
from larger-scale solar projects not only has the potential to power critical infrastructure, but also has the potential to power local homes and/or businesses. Because long-term electricity data for the island was not available, further analysis into the impacts of larger community solar projects could not be estimated (e.g., percent solar power provided to the entire island). Another option could be to sell the electricity to neighboring islands (e.g., Vieques) if there is excess. It is important to note that $17.7 \mathrm{MW}$ of potential PV was identified, which is considerably more than the $4 \mathrm{MW}$ of diesel-generated electricity currently used to power the entire island. However, because solar power is intermittent (e.g., the sun does not always shine), further analysis would be needed to determine financially viable potential sizing of community solar projects.

Table 13. Summary of SAM Modeling Inputs and Results for Potential Areas for PV

\begin{tabular}{|l|c|c|c|c|c|c|}
\hline & $\begin{array}{c}\text { Culebra } \\
\text { Landfill }\end{array}$ & Muni Lot \#1 & $\begin{array}{c}\text { Muni Lot } \\
\text { \#2 }\end{array}$ & $\begin{array}{c}\text { PRIDCO } \\
\text { Roof }\end{array}$ & Lot \#3 & Total \\
\hline $\begin{array}{l}\text { PV System Size } \\
\text { (kW) }\end{array}$ & 1,440 & 4,800 & 1,120 & 360 & 10,000 & 17,720 \\
\hline $\begin{array}{l}\text { Annual } \\
\text { Electricity } \\
\text { Generation } \\
\text { (kWh) }\end{array}$ & $2,198,439$ & $7,328,129$ & $1,709,897$ & 545,724 & $15,266,934$ & $27,049,123$ \\
\hline $\begin{array}{l}\text { PPA Analysis } \\
\text { First-Year PPA } \\
\text { Price (ф/kWh) }\end{array}$ & 9.17 & 9.17 & 9.17 & 9.23 & 9.17 & 9.17 \\
\hline $\begin{array}{l}\text { Levelized Cost of } \\
\text { Energy (ф/kWh) }\end{array}$ & 10.18 & 10.18 & 10.18 & 10.25 & 10.18 & 10.19 \\
\hline $\begin{array}{l}\text { Direct Purchase } \\
\text { Net Present } \\
\text { Value (\$) }\end{array}$ & $\$ 3,503,203$ & $\$ 11,677,512$ & $\$ 2,724,687$ & $\$ 865,537$ & $\$ 24,328,238$ & $\$ 43,099,177$ \\
\hline $\begin{array}{l}\text { Direct Purchase } \\
\text { Simple Payback } \\
\text { (years) }\end{array}$ & 6.8 & 6.8 & 6.8 & 6.8 & 6.8 & 6.8 \\
\hline
\end{tabular}

a The simple payback accounts for PV panel degradation over the 25-year life of the system.

This initial high-level energy resilience analysis for critical infrastructure on Culebra indicates that renewable energy hybrid microgrids (a diesel generator plus PV plus battery storage) appear to be economically viable; however, further analysis is needed. More detailed informationgathering and analysis would be needed to optimize the mix of diesel, PV, and battery. This more detailed energy resilience analysis can be done using REopt ${ }^{10}$ an optimization tool NREL developed to analyze the optimal mix of renewable energy, conventional energy generation, and energy storage for various types of projects, including microgrids.

\footnotetext{
10 "REopt: Renewable Energy Integration and Optimization," National Renewable Energy Laboratory, accessed October 2018, https://reopt.nrel.gov/.
} 
The major next steps are as follows:

- Obtain electric utility data for all of the critical infrastructure sites; hourly data is preferable, but monthly data would provide a good starting point.

- Obtain electric utility data for the entire island if community solar is of interest; monthly electricity data would most likely be sufficient.

- Collect information on existing backup power systems.

- Obtain single line diagrams of the power grid.

- Start conversations with the local electric utility provider PREPA; make PREPA aware of potential future plans and work with them to identify any potential barriers to future projects.

- Assess environmental conditions and potential contaminants at the potential areas for PV. ${ }^{11}$

- Develop a request for proposals (RFP) ${ }^{12}$ to attract major solar developers that are active in Puerto Rico to support these projects.

- Identify solar curriculum programs, job training programs, and collaborators in Puerto Rico to produce local qualified solar installers.

- Identify potential federal partners/programs, including the Federal Emergency Management Agency (FEMA), the U.S. Department of Agriculture (USDA), the U.S. Economic Development Administration (EDA), and the Puerto Rico Department of Housing (PRDOH), who are looking to leverage funds for solar energy projects; Appendix E provides further information on resources provided by EPA.

\footnotetext{
11 "Targeted Brownfields Assessments (TBA)," U.S. Environmental Protection Agency, accessed October 2018, https://www.epa.gov/brownfields/targeted-brownfields-assessments-tba.

${ }^{12}$ A Solar RFP Template is available from the U.S. Department of Energy at https://www.energy.gov/sites/prod/files/2015/08/f25/RFP\%20Template\%20for\%20Gridtied $\% 20$ PV $\% 20$ Project.docx.
} 


\section{Appendix A: Climate Data}

Culebra, Puerto Rico, is in the Caribbean Sea between the main island of Puerto Rico and the U.S. Virgin Islands. The island is at an average elevation of 82 feet above sea level, and its latitude and longitude are $18.3104^{\circ} \mathrm{N}, 65.3031^{\circ} \mathrm{W}$, respectively. Culebra has a warm and humid climate with little seasonal temperature variation throughout the year. Table A-1 is a summary of the weather on Culebra.

Table A-1. Culebra, Puerto Rico, Historic Weather Summary

\begin{tabular}{|c|c|c|c|c|c|c|c|c|c|c|c|c|c|}
\hline \multicolumn{14}{|c|}{ Average Temperature } \\
\hline & ANNUAL & JAN & FEB & MAR & APR & MAY & JUN & JUL & AUG & SEP & OCT & NOV & DEC \\
\hline Degrees $\mathrm{F}$ & 79.7 & $\begin{array}{ll}76.7 \\
\end{array}$ & 76.7 & 76.9 & 78.3 & 80.2 & 81.9 & 82.4 & 82.5 & 82.0 & 81.2 & 79.7 & 77.6 \\
\hline \multicolumn{14}{|c|}{ Average High Temperature } \\
\hline & ANNUAL & JAN & FEB & MAR & APR & MAY & JUN & JUL & AUG & SEP & OCT & NOV & DEC \\
\hline Degrees $\mathrm{F}$ & 86.5 & 83.8 & 84.0 & 84.1 & 84.9 & 86.4 & 88.0 & 88.9 & 89.2 & 89.0 & 88.2 & 86.7 & 84.6 \\
\hline \multicolumn{14}{|c|}{ Average Low Temperature } \\
\hline & ANNUAL & JAN & FEB & MAR & APR & MAY & JUN & JUL & AUG & SEP & OCT & NOV & DEC \\
\hline Degrees F & 72.9 & 69.6 & 69.5 & 69.7 & 71.7 & 74.0 & 75.8 & 75.9 & 75.9 & 75.1 & 74.2 & 72.7 & 70.6 \\
\hline \multicolumn{14}{|c|}{ Highest Recorded Temperature } \\
\hline & ANNUAL & JAN & FEB & MAR & APR & MAY & JUN & JUL & AUG & SEP & OCT & NOV & DEC \\
\hline Degrees $\mathrm{F}$ & 99.0 & 92.0 & 95.0 & 97.0 & 91.0 & 96.0 & 98.0 & 99.0 & 98.0 & 97.0 & 98.0 & 97.0 & 95.0 \\
\hline \multicolumn{14}{|c|}{ Lowest Recorded Temperature } \\
\hline & ANNUAL & JAN & FEB & MAR & APR & MAY & JUN & JUL & AUG & SEP & OCT & NOV & DEC \\
\hline Degrees $\mathrm{F}$ & 55.0 & 58.0 & 59.0 & 55.0 & 58.0 & 65.0 & 63.0 & 68.0 & 67.0 & 69.0 & 65.0 & 65.0 & 63.0 \\
\hline \multicolumn{14}{|c|}{ Average Precipitation } \\
\hline & ANNUAL & JAN & FEB & MAR & APR & MAY & JUN & JUL & AUG & SEP & OCT & NOV & DEC \\
\hline inches & 44.7 & 2.7 & 1.9 & 2.0 & 3.5 & 4.0 & 2.5 & 3.3 & 4.3 & 6.0 & 4.9 & 6.3 & 3.2 \\
\hline \multicolumn{14}{|c|}{ Average Number of Days with Precipitation } \\
\hline & ANNUAL & JAN & FEB & MAR & APR & MAY & JUN & JUL & AUG & SEP & OCT & NOV & DEC \\
\hline Days & 180.0 & 16.0 & 14.0 & 11.0 & 12.0 & 14.0 & 12.0 & 16.0 & 17.0 & 16.0 & 18.0 & 17.0 & 17.0 \\
\hline \multicolumn{14}{|c|}{ Heating Degree Days } \\
\hline & ANNUAL & JAN & FEB & MAR & APR & MAY & JUN & JUL & AUG & SEP & OCT & NOV & DEC \\
\hline Days & 5242.0 & 352.0 & 318.0 & 361.0 & 381.0 & 453.0 & 496.0 & 530.0 & 527.0 & 504.0 & 494.0 & 435.0 & 391.0 \\
\hline \multicolumn{14}{|c|}{ Cooling Degree Days } \\
\hline & ANNUAL & JAN & FEB & MAR & APR & MAY & JUN & JUL & AUG & SEP & OCT & NOV & DEC \\
\hline Days & 0.0 & 0.0 & 0.0 & 0.0 & 0.0 & 0.0 & 0.0 & 0.0 & 0.0 & 0.0 & 0.0 & 0.0 & 0.0 \\
\hline \multicolumn{14}{|c|}{ Growing Degree Days } \\
\hline & ANNUAL & JAN & FEB & MAR & APR & MAY & JUN & JUL & AUG & SEP & OCT & NOV & DEC \\
\hline Days & 10717.0 & 817.0 & 738.0 & 826.0 & 831.0 & 918.0 & 946.0 & 995.0 & 992.0 & 954.0 & 959.0 & 885.0 & 856.0 \\
\hline \multicolumn{14}{|c|}{ Average Length of Day } \\
\hline & ANNUAL & JAN & FEB & MAR & APR & MAY & JUN & JUL & AUG & SEP & OCT & NOV & DEC \\
\hline Hours & 12.5 & $\begin{array}{ll}11.6 \\
\end{array}$ & 11.9 & 12.4 & 12.9 & 13.4 & 13.6 & 13.5 & 13.1 & 12.6 & 12.1 & 11.6 & 11.4 \\
\hline \multicolumn{14}{|c|}{ Average Daily Global Solar Radiation } \\
\hline & ANNUAL & JAN & FEB & MAR & APR & MAY & JUN & JUL & AUG & SEP & OCT & NOV & DEC \\
\hline $\mathrm{kWh} / \mathrm{m}^{2}$ & 6.1 & 4.9 & 5.7 & 6.6 & 7.0 & 6.9 & 7.0 & 7.0 & 6.9 & 6.2 & 5.6 & 4.8 & 4.6 \\
\hline
\end{tabular}

Source: Weatherbase, accessed October 2018, http://www.weatherbase.com. 


\section{Appendix B: General Building and Facility Information}

\section{General Building Information}

A. What are the names of the buildings?

Health Clinic, Police Station, Fire Station, Municipal Building, and WWTP

B. What are the building addresses?

All buildings and facilities are located on Culebra

C. What is the square footage of the buildings?

Health Clinic $=11,000 \mathrm{ft}^{2}$

Police Station $=1,700 \mathrm{ft}^{2}$

Fire Station $=1,500 \mathrm{ft}^{2}$

Municipal Building $=20,000 \mathrm{ft}^{2}$

$\mathrm{WWTP}=0.2$ MGD capacity (a majority of the electricity use is not in the buildings but in the treatment operation)

D. What are the building schedules? (e.g., occupied 7 a.m.-5 p.m. M-F, closed weekends.)

Health Clinic, Police Station, Fire Station, WWTP $=24 / 7$

Municipal Building = M-F 7 a.m. to 6 p.m.

\section{Building Envelope Information}

A. What is the wall construction? (e.g., steel framed walls with R-19 batt insulation and brick exterior.)

Concrete walls

B. What is the roof construction? (e.g., built-up white roof with R-30 rigid insulation.)

White built-up roofs

C. What is the window construction? (e.g., double-pane clear windows with metal frames.)

Clear single-pane windows

\section{HVAC Information}

A. What are the thermostat set points for space heating and cooling? (e.g., heating $70^{\circ} \mathrm{F}$ occupied and $64^{\circ} \mathrm{F}$ unoccupied; cooling $74^{\circ} \mathrm{F}$ occupied and $80^{\circ} \mathrm{F}$ unoccupied.)

$70-72^{\circ} \mathrm{F}$

B. What type of HVAC system does the building have? (e.g., built-up variable air volume, packaged rooftop units with furnace.)

Health Center and Municipal Building = packaged air-conditioning units

Police Station and Fire Station = window air-conditioning units 


\section{Lighting Information}

A. What type of interior lights does the building have? (e.g., T-8 fluorescent lamps with electronic ballasts.)

Linear fluorescent T-8 and T-12 lamps, CFLs, and some LEDs

B. What type of lighting controls does the building have? (e.g., daylighting, occupancy sensors.)

Standard switched lighting are most common

\section{Plug Loads, Data Center, and Backup Generator Information}

A. What are the predominant plug loads in the building? (e.g., computer equipment, cooking equipment.)

Standard office building plug loads with computer workstations

B. Are smart plug load power strips in use at the site? (e.g., power strips that put computer equipment into sleep mode when not in use.)

No

C. Is there a large data center? Include the number of servers, type of data center cooling system, and electrical load associated with the data center.

No

D. What backup power system does the building have? (e.g., 100-kW diesel generator.) Include fuel source, manufacturer, capacity, and age.

Health Center $=35 \mathrm{~kW} / 41 \mathrm{kVA}$ (no nameplate but estimated based on size) by Himoinsa

Police Station $=60 \mathrm{~kW} / 70 \mathrm{kVA}$ by Whisperwatt

Fire Station $=17 \mathrm{~kW} / 20 \mathrm{kVA}$ by Kubota

Municipal Building = no backup generator seen on site

WWTP $=320 \mathrm{~kW} / 375 \mathrm{kVA}$ by Cummins Power Generation

\section{Facility Management}

A. What are your energy efficiency goals for the site? (e.g., 20\% energy reduction, net-zero.)

Increase energy resilience in critical infrastructure

Reduce electricity use and incorporate renewable energy technologies where it's economically feasible

\section{Building Controls}

A. Does the site have an energy management and control system or direct digital control building automation system? (e.g., Alerton, Trane Tracer, etc.) Include manufacturer, version, and age.

None of the buildings have automated building controls 


\section{Utilities}

A. Please provide us with a copy of your utility rate schedules and a copy of the last 3 years of utility bills (e.g., electric, natural gas, steam, heating oil, diesel, water/sewer).

No utility provided but electricity use was estimated using building energy modeling (eQUEST) 


\section{Appendix C: Building Energy Modeling}

A graphical representation of the building energy models developed in eQUEST for the Police Station, Fire Station, Health Center, and Municipal Building are shown in Figure C-1, Figure C-2, Figure C-3, and Figure C-4, respectively. The geometry of the buildings was simplified for modeling purposes while still allowing accurate simulations of energy transfer through all surfaces in the building.

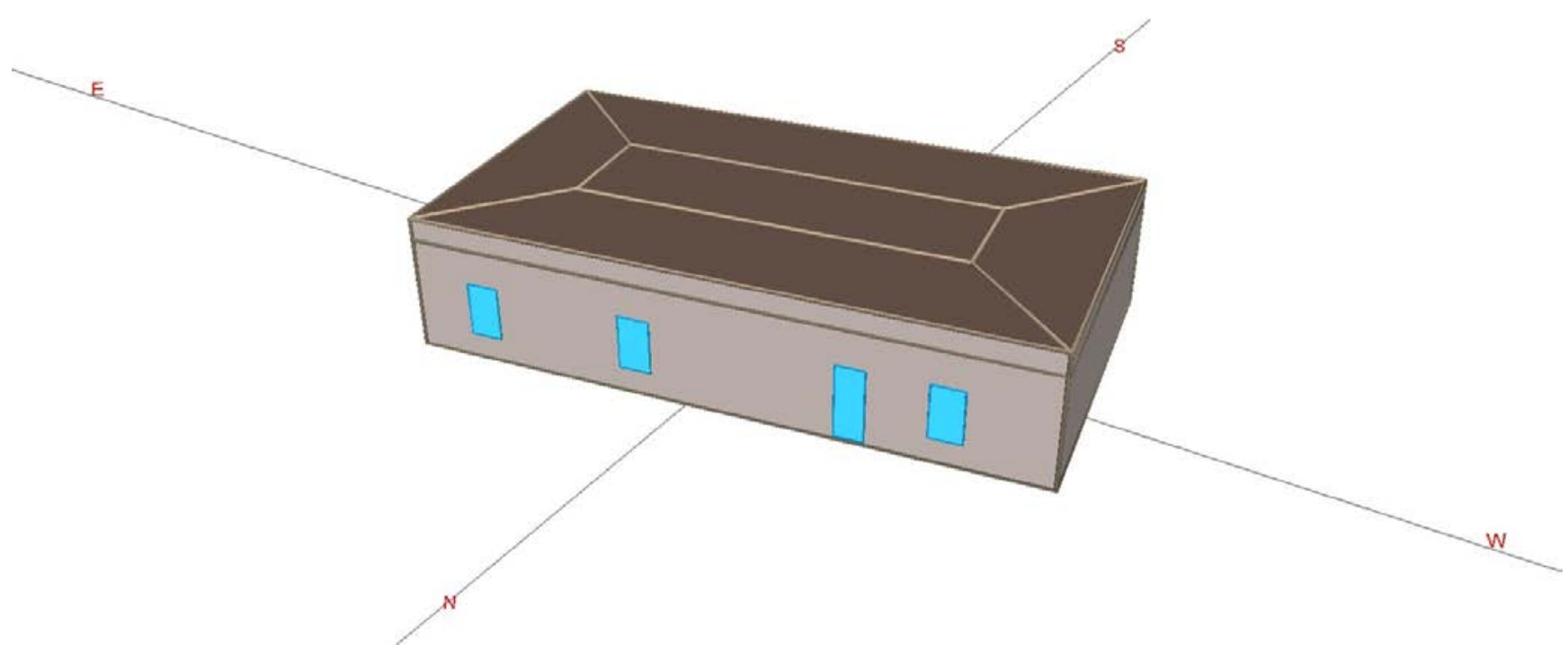

Figure C-1. Police station on Culebra eQUEST model representation

Image generated using eQUEST

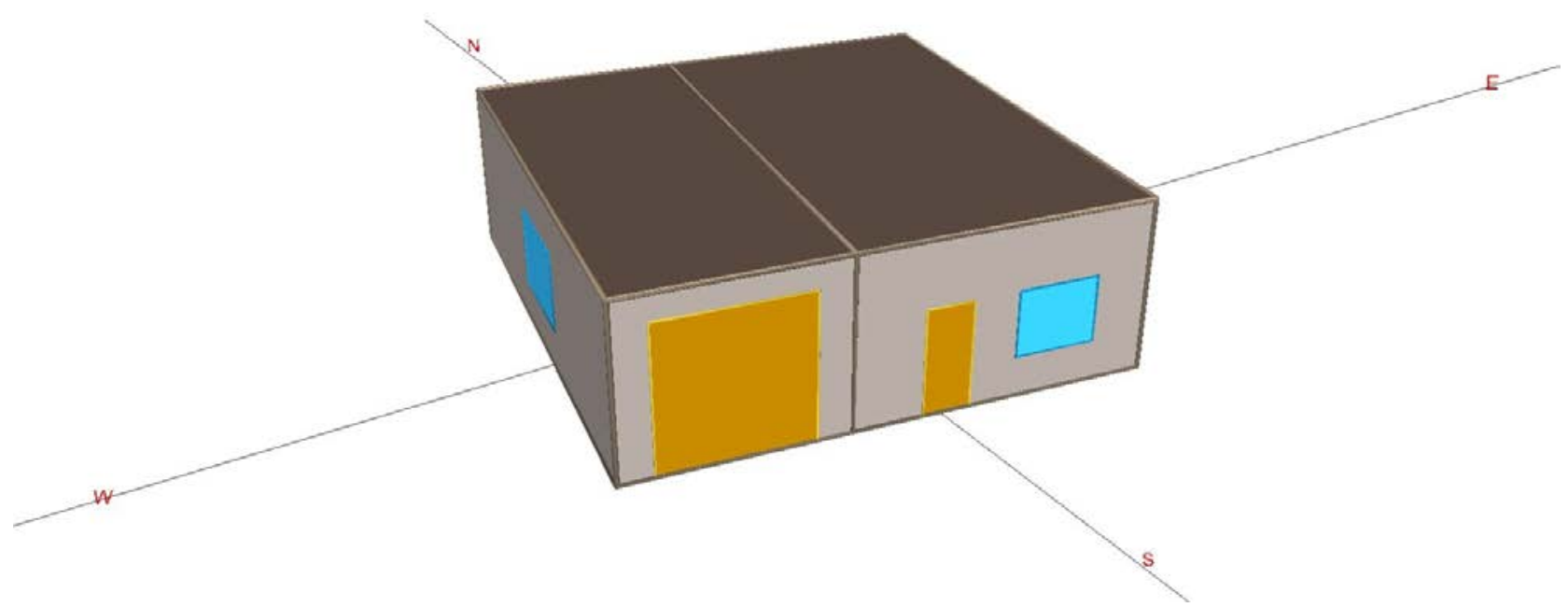

Figure C-2. Fire station on Culebra eQUEST model representation

Image generated using eQUEST 


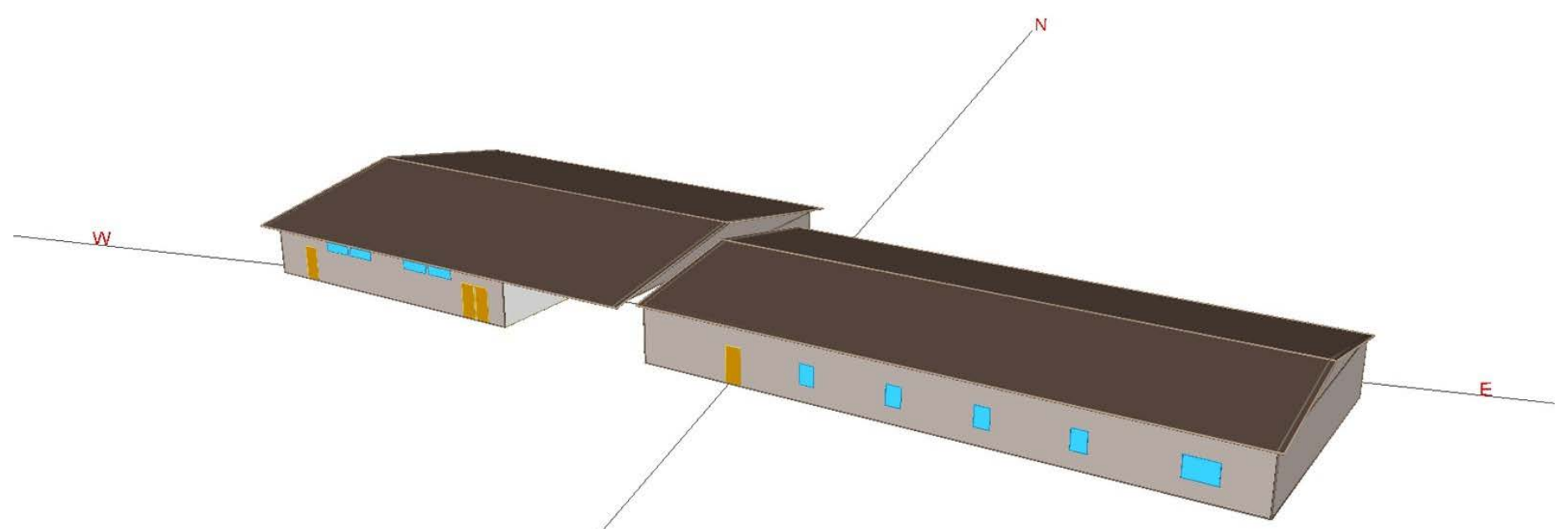

Figure C-3. Health center on Culebra eQUEST model representation

Image generated using eQUEST

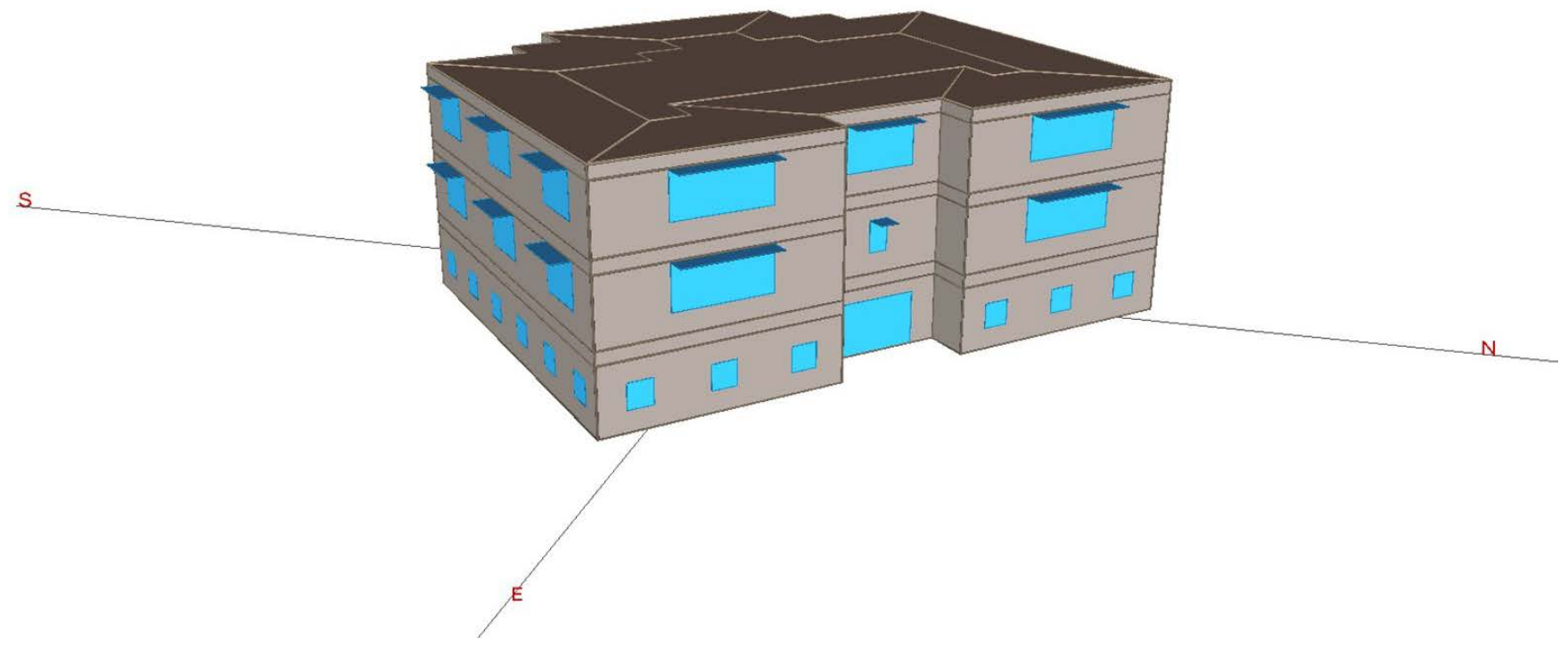

Figure C-4. Municipal building on Culebra eQUEST model representation

Image generated using eQUEST

Estimates of the current energy use breakdown at the Police Station, Fire Station, Health Center, and Municipal Building were generated using the eQUEST building energy model and are given in Figure C-5, Figure C-6, Figure C-7, and Figure C-8, respectively. 

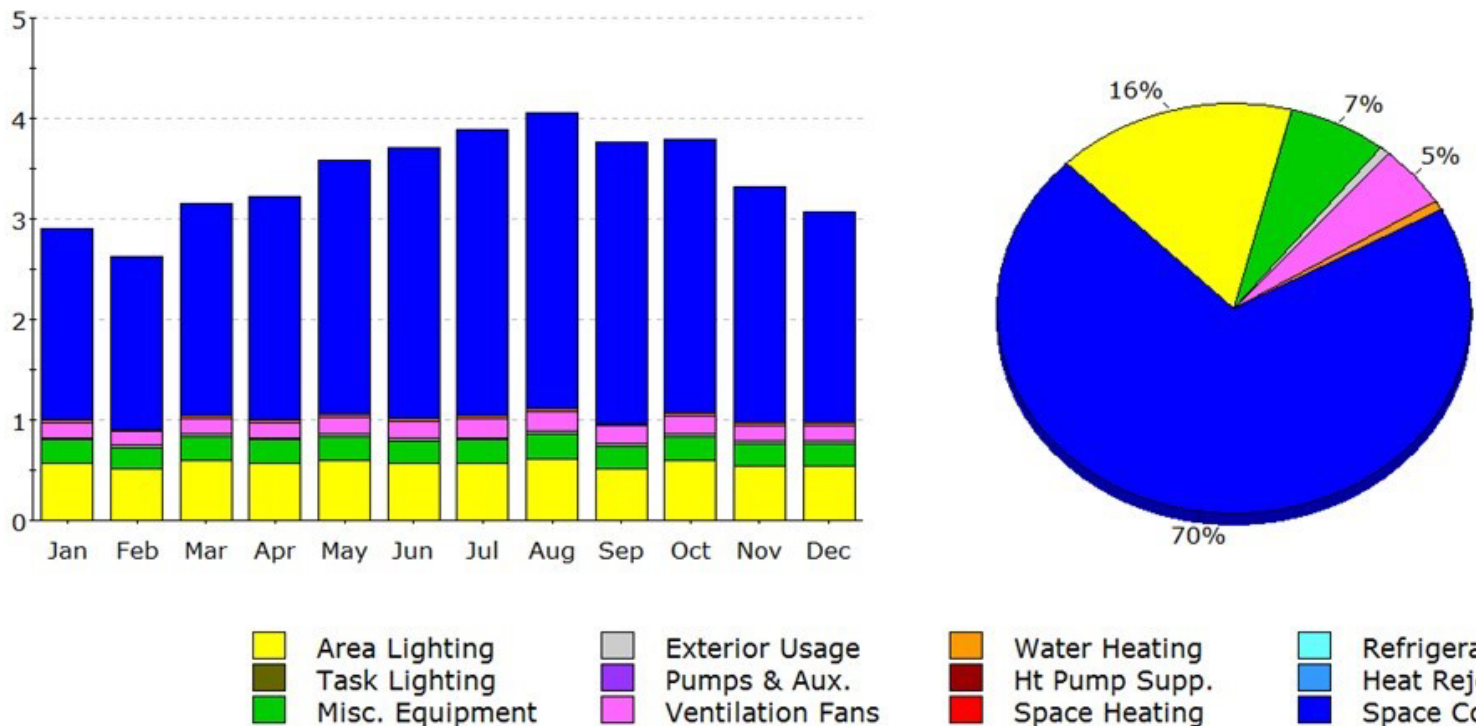
Water Heating
Ht Pump Supp Ht Pump Supp.

Refrigeration Heat Rejection Space Cooling

Figure C-5. eQUEST-calibrated baseline energy use estimates for the police station on Culebra Figures generated using eQUEST

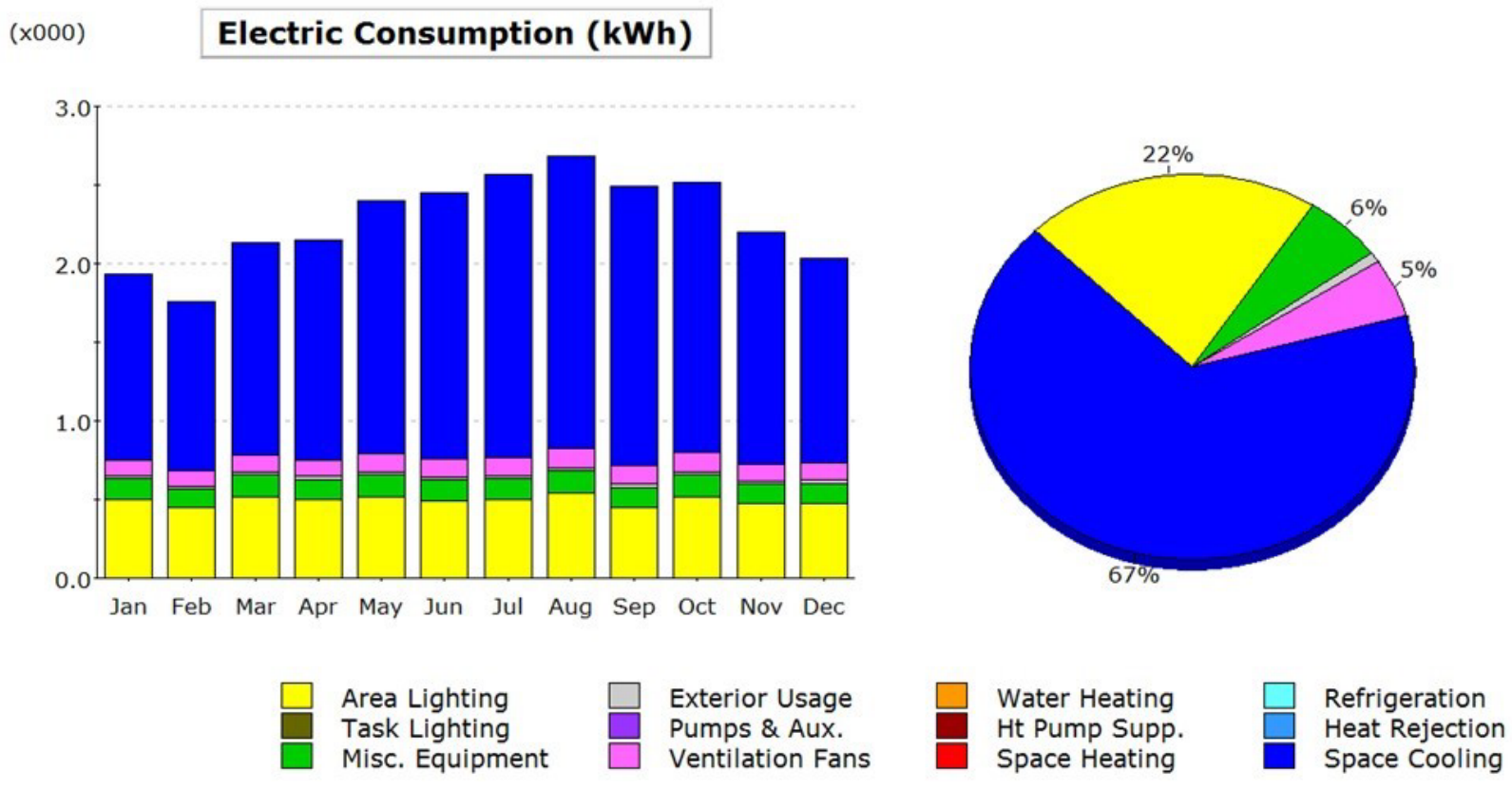

Figure C-6. eQUEST-calibrated baseline energy use estimates for the fire station on Culebra

Figures generated using eQUEST 

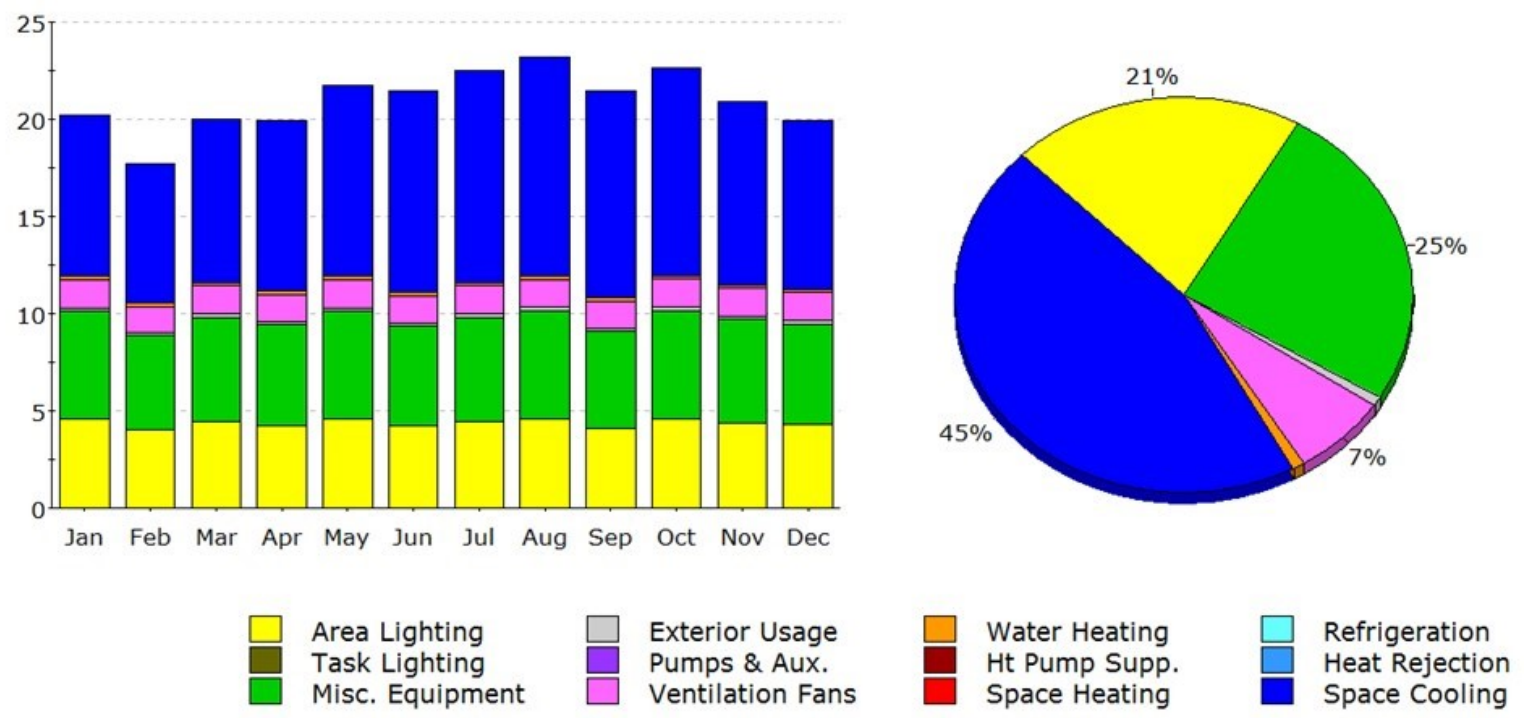

Figure C-7. eQUEST-calibrated baseline energy use estimates for the health center on Culebra

Figures generated using eQUEST

\section{Electric Consumption (kWh)}
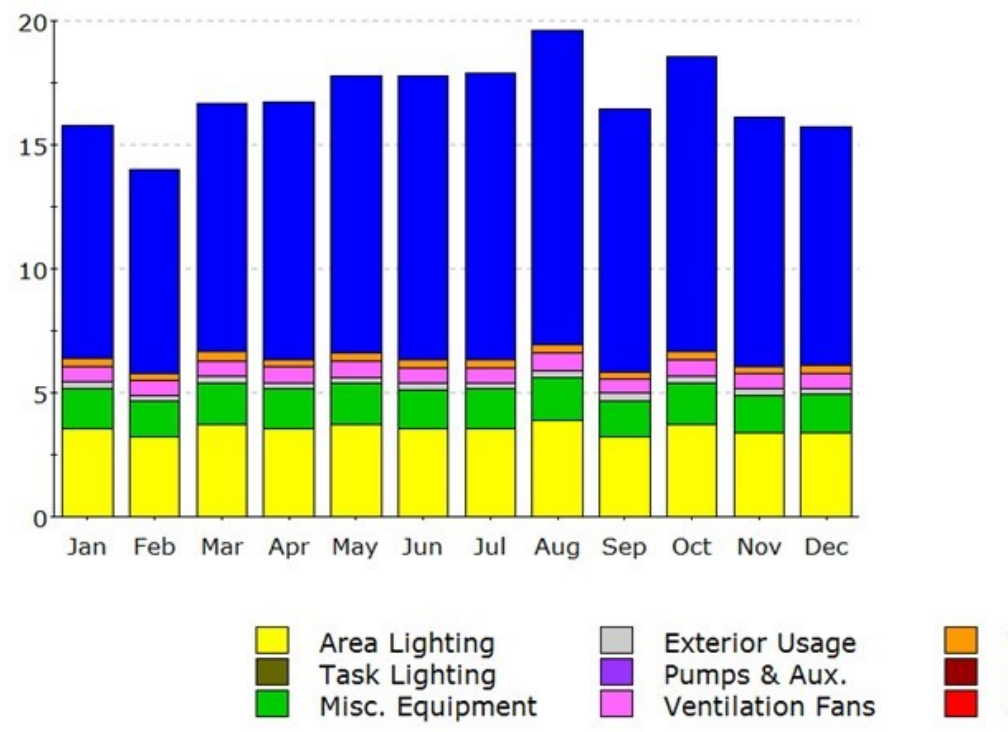

Water Heating Ht Pump Supp. Space Heating

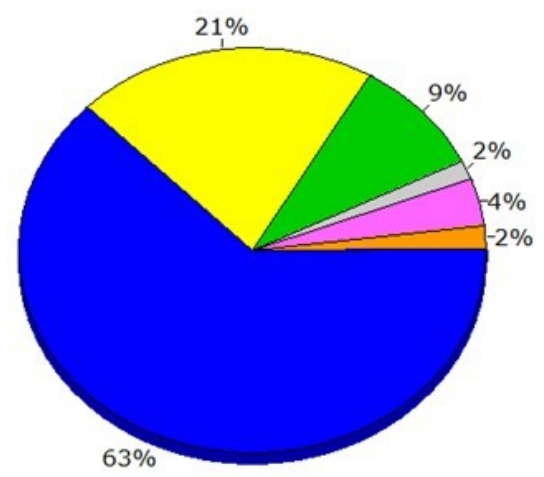

Figure C-8. eQUEST-calibrated baseline energy use estimates for the municipal building on Culebra

Figures generated using eQUEST 


\section{Appendix D: Detailed Images of Potential Areas for PV}

Aerial Google Earth images that detail the potential areas for PV are shown in Figure D-1, Figure D-2, Figure D-3, and Figure D-4, respectively. These images are all taken from Google Earth at the same elevation, so relative sizes can be compared.

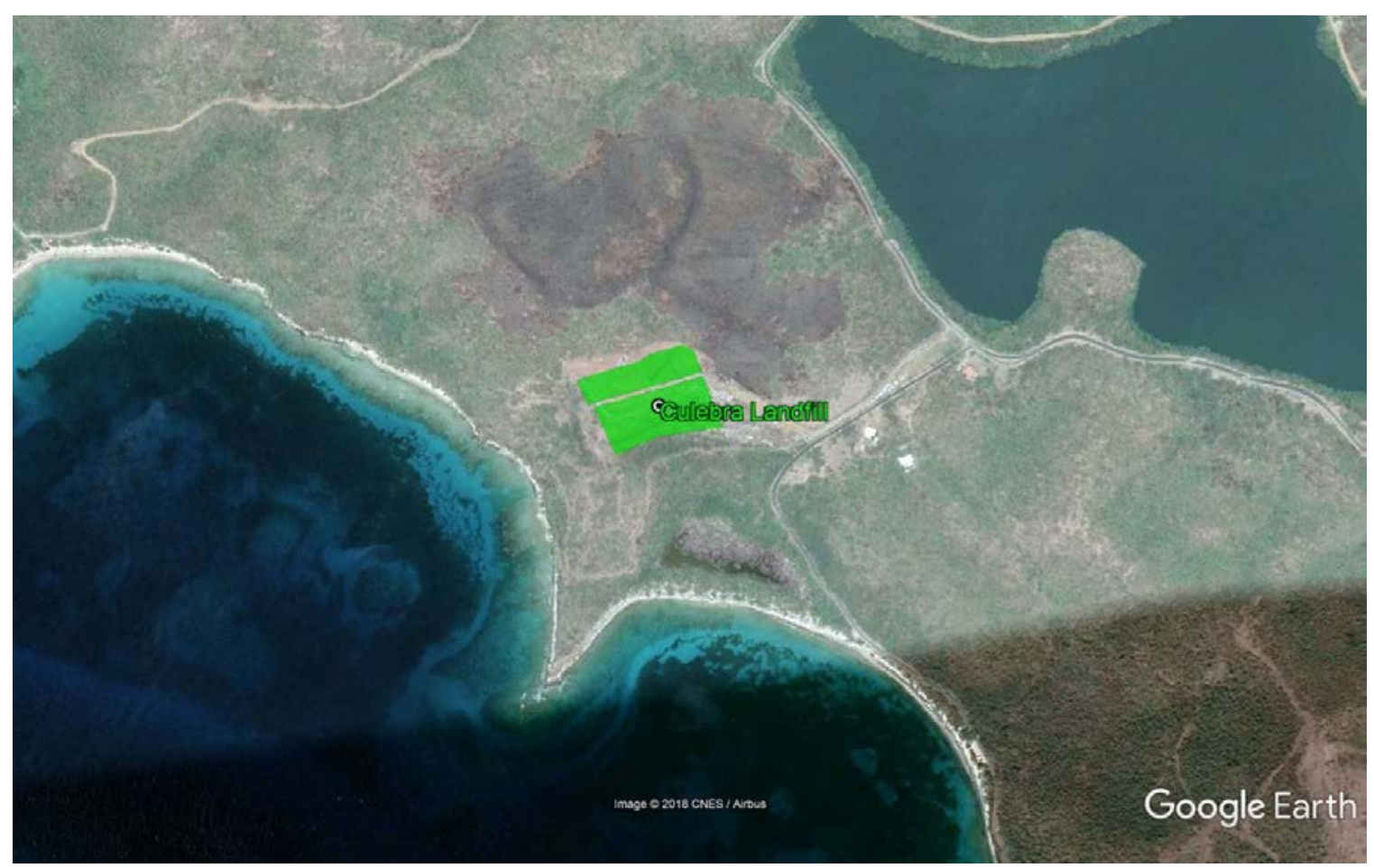

Figure D-1. Potential area for PV at Culebra Landfill, aerial view

(C) 2018 Google Earth, alterations by James Salasovich, NREL 


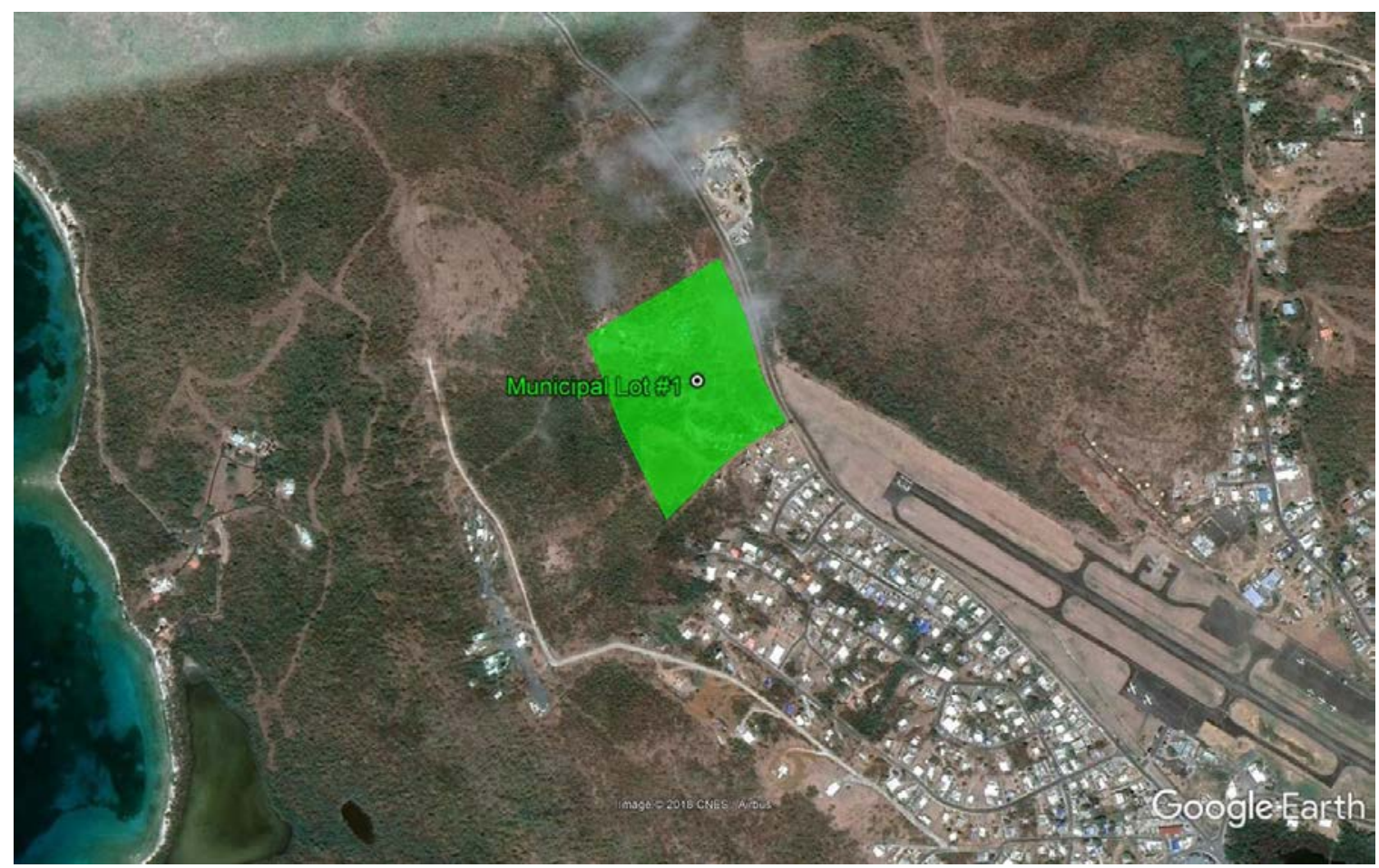

Figure D-2. Potential area for PV at Municipal Lot \#1, aerial view

(C) 2018 Google Earth, alterations by James Salasovich, NREL

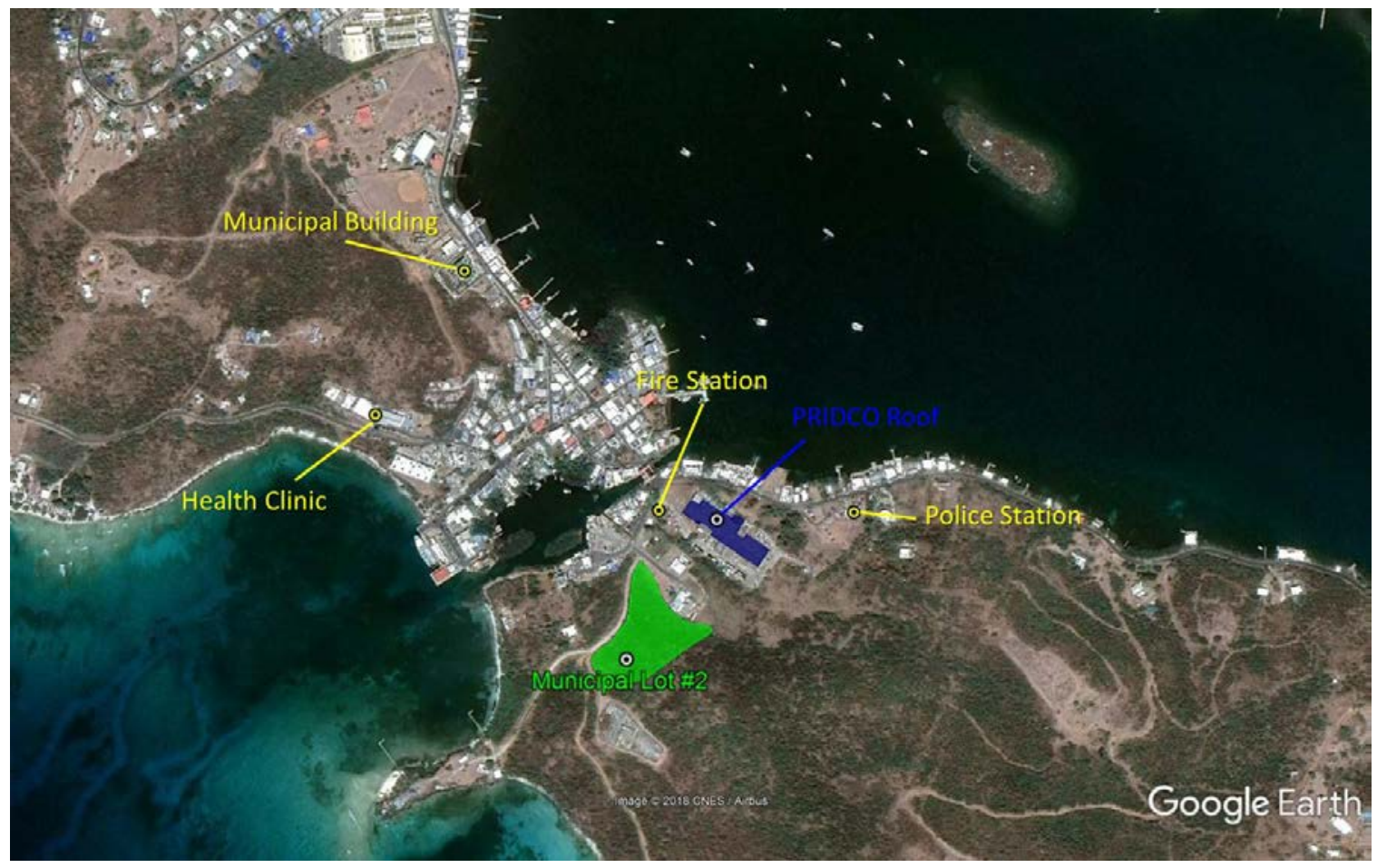

Figure D-3. Potential area for PV at Municipal Lot \#2 and PRIDCO Roof, aerial view

(C) 2018 Google Earth, alterations by James Salasovich, NREL 


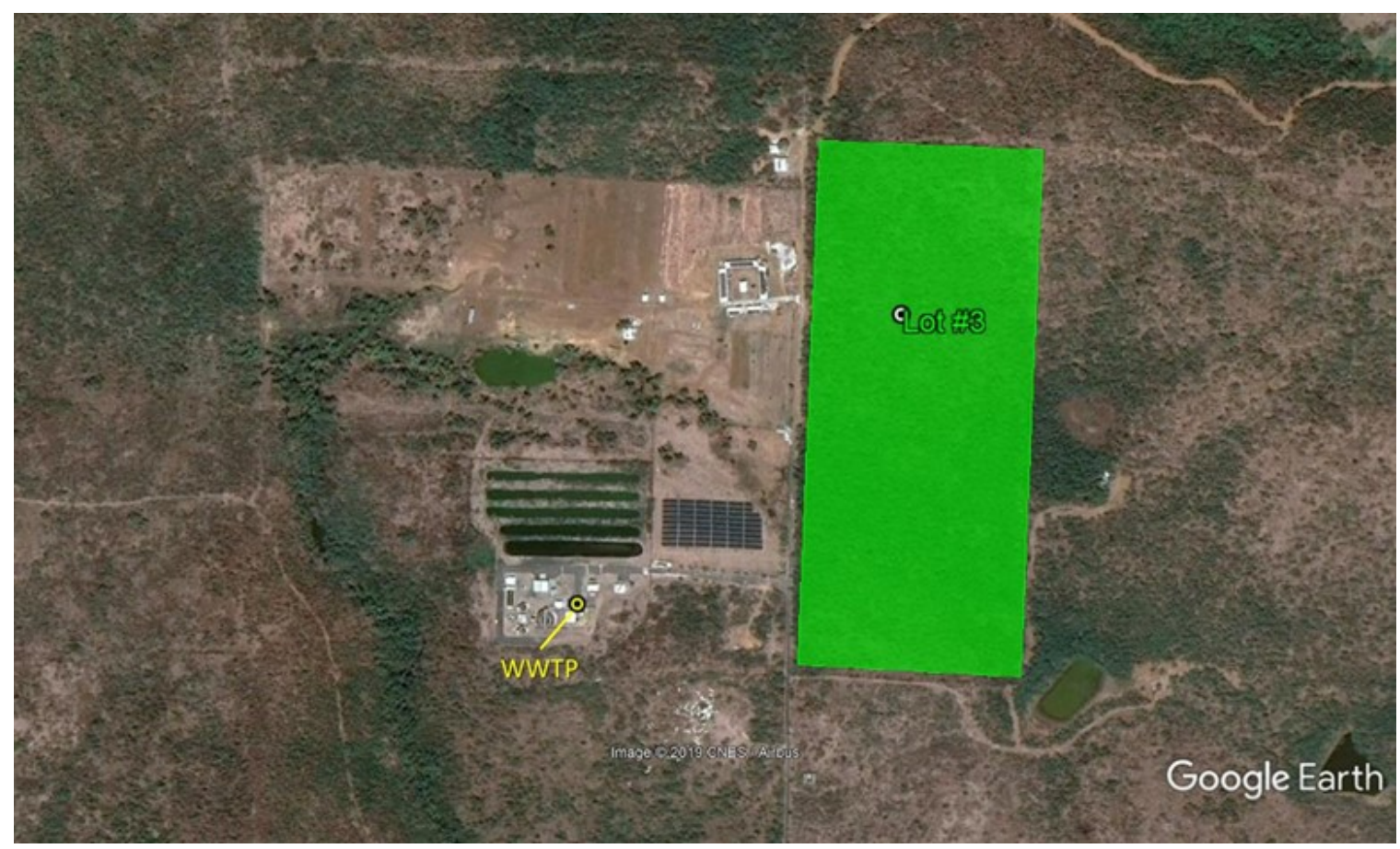

Figure D-4. Potential area for PV at Lot \#3, aerial view

(C) 2018 Google Earth, alterations by James Salasovich, NREL

A brief description of each of the potential sites for PV is given below.

Culebra Landfill—Located off PR-251, 2.3 km northwest of the Benjamín Rivera Noriega Airport, Flamenco Ward (coordinates: 18¹9’20.66 N, 65¹9”18.50” W).

Culebra Municipal Lot \#1 - Located off PR-251, west of the Benjamín Rivera Noriega Airport (coordinates: $18^{\circ} 18^{\prime} 53.77^{\prime \prime} \mathrm{N},-65^{\circ} 18^{\prime} 36.33^{\prime \prime} \mathrm{W}$ ).

Culebra Municipal Lot \#2 - Located south of the Culebra Community Library (coordinates: $\left.18^{\circ} 18^{\prime} 2.50^{\prime \prime} \mathrm{N},-65^{\circ} 17^{\prime} 59.41^{\prime \prime} \mathrm{W}\right)$.

Culebra Wastewater Treatment Plant and Lot \#3 - Located off PR-250 in the center portion of the island (coordinates: $18^{\circ} 18^{\prime} 59.29^{\prime \prime} \mathrm{N}, 65^{\circ} 16^{\prime} 47.26^{\prime \prime} \mathrm{W}$ ).

PRIDCO Property - Parque Industrial Playa Sardina II-Located off the southeast exist of the Culebra draw bridge on CII Escudero Road (coordinates: $18^{\circ} 18^{\prime} 05.6^{\prime \prime} \mathrm{N}, 65^{\circ} 17^{\prime} 55.9^{\prime \prime} \mathrm{W}$ ). 


\section{Appendix E: EPA Resources}

The EPA Region 2 Brownfields Program has many public resources that are available to help project development on brownfields sites. EPA's Brownfields Program collaborates with other EPA programs, other federal partners, and state agencies to identify and make available resources that can be used for Brownfields activities. In addition to direct Brownfields funding, EPA also provides technical information on Brownfields financing matters.

\section{Targeted Brownfields Assessments}

The Municipality of Culebra may have brownfield sites that are eligible for investigative work under EPA's Targeted Brownfield Assessment (TBA) program. EPA's TBA program helps states, tribes, and municipalities minimize the uncertainties of contamination often associated with brownfields. This program supplements other efforts under the TBA program to promote the cleanup and redevelopment of brownfields, including the reuse of sites for solar/renewable energy projects. TBAs are conducted by an EPA contractor on behalf of an eligible entity. Services include site assessments, cleanup options and cost estimates, and community outreach. Services are for an average of $\$ 100,000$. For additional information and contacts, visit https://www.epa.gov/brownfields/targeted-brownfields-assessments-tba.

\section{Environmental Workforce Development and Job Training Program}

Culebra may also consider learning more about EPA's Environmental Workforce Development and Job Training (EWDJT) Grants. The EWDJT Program provides funding and technical assistance for environmental cleanup and health and safety training to organizations currently training residents within targeted communities who are seeking new skills and greater earning potential. The program helps to clean up brownfields and other environmental conditions, spurs sustainable economic development, and creates a pool of skilled workers to be employed in the environmental field, especially in areas of renewable energy, such as solar. For additional information on the EWDJT program, visit https:/www.epa.gov/brownfields/brownfields-epasenvironmental-workforce-development-and-job-training-program.

\section{Hazardous Materials Training Research Institute}

Technical assistance is also available from the Hazardous Materials Training Research Institute (HMTRI). HMTRI has worked under cooperative agreement with EPA on the Brownfields initiative since its inception in 1994, providing technical assistance to EPA-funded EWDJT grantees and prospective grantees. Technical assistance includes conducting annual meetings and webinars for all funded and prospective EWDJT grantees, developing and maintaining the Brownfields Toolbox website and outreach listserv, establishing and maintaining a mentor-link program, and conducting biweekly Professional Learning Community conference calls that feature various aspects of building and sustaining a successful job development program. For additional information on HMTRI, visit https://hmtri.org/.

\section{Advanced Technology Environmental and Energy Center}

Technical assistance is also available from the Advanced Technology Environmental and Energy Center (ATEEC). ATEEC is a national center that promotes and supports environmental and energy technology education to address the needs of the national and global workforce. ATEEC is a National Science Foundation Center of Excellence funded since 1994 whose mission is the 
advancement of environmental and energy technology education through curriculum, professional, and program development and improvement. ATEEC provides reports on energy technologies, services, and careers. For additional information on ATEEC, visit http://ateec.org/.

\section{PathStone Corporation}

An additional partner is the PathStone Corporation. PathStone is a nonprofit community development and human service organization providing services to low-income families and economically depressed communities throughout New York, Pennsylvania, New Jersey, Ohio, Indiana, Virginia, Vermont, and Puerto Rico. PathStone has successfully operated a wide array of programs funded by federal, state, local, faith-based, and private sources since 1969. This organization is the recipient of two EPA EWDJT grants. Learn more about how PathStone Corporation has been successful in receiving federal and state funds for workforce development at https://pathstone.org/workforce-development/. 